NBER WORKING PAPER SERIES

TEMPORARILY UNSTABLE GOVERNMENT DEBT AND INFLATION

\author{
Troy Davig \\ Eric M. Leeper \\ Working Paper 16799 \\ http://www.nber.org/papers/w16799 \\ NATIONAL BUREAU OF ECONOMIC RESEARCH \\ 1050 Massachusetts Avenue \\ Cambridge, MA 02138 \\ February 2011
}

We thank Pierre-Olivier Gourinchas and Ayhan Kose for helpful comments and Todd Walker for many useful conversations. The views expressed are those of the authors and do not reflect the position of Barclays Capital, its management, or the National Bureau of Economic Research.

NBER working papers are circulated for discussion and comment purposes. They have not been peerreviewed or been subject to the review by the NBER Board of Directors that accompanies official NBER publications.

(C) 2011 by Troy Davig and Eric M. Leeper. All rights reserved. Short sections of text, not to exceed two paragraphs, may be quoted without explicit permission provided that full credit, including $\odot$ notice, is given to the source. 
Temporarily Unstable Government Debt and Inflation

Troy Davig and Eric M. Leeper

NBER Working Paper No. 16799

February 2011

JEL No. E31,E52,E62,E63

\begin{abstract}
$\underline{\text { ABSTRACT }}$
Many advanced economies are heading into an era of fiscal stress: populations are aging and governments have made substantially more promises of old-age benefits than they have made provisions to finance. This paper models the era of fiscal stress as stemming from relentlessly growing promised government transfers that initially are fully honored, being financed by new sales of government debt that bring forth higher future income taxes. As debt levels and tax rates rise, the population's tolerance for taxation declines and the probability of reaching the fiscal limit increases. At the limit a fixed tax rate is adopted, adjustments in taxes no longer stabilize debt, and some new stabilizing combination of policies must arise. We examine how, in the period before the fiscal limit, rapidly rising debt interacts with expectations of how and when policies will adjust. Temporarily explosive debt has no effect on inflation if households expect all adjustments to occur through entitlements reform, but if households believe it is possible that in the future monetary policy will shift from targeting inflation to stabilizing debt, then debt feeds directly into the path of inflation and monetary policy can no longer control inflation. News that reduces expected primary surpluses can bring future inflation into the present, well before the news shows up in fiscal measures.
\end{abstract}

Troy Davig

Barclays Capital

Troy.Davig@barclayscapital.com

Eric M. Leeper

Department of Economics

304 Wylie Hall

Indiana University

Bloomington, IN 47405

and Monash University, Australia

and also NBER

eleeper@indiana.edu 


\title{
Temporarily Unstable Government Debt AND INFLATION*
}

\author{
Troy Davig ${ }^{\dagger}$ and Eric M. Leeper ${ }^{\ddagger}$
}

February 7, 2011

\section{INTRODUCTION}

Every economy faces a "fiscal limit" - a point beyond which tax collections can no longer rise and government expenditures cannot be further reduced. At that limit, primary fiscal surpluses are at their maximum. The expected present value of those maximum surpluses, according to conventional bond valuation reasoning, yields the largest value of government debt that the economy can support.

Fiscal limits may be imposed by either economic or political forces. Economies face a natural fiscal limit that arises because most taxes on factor incomes are subject to a Laffer curve, which implies an upper bound on revenues as a share of GDP. Many European countries may be approaching the peak of their Laffer curves for labor taxes, according to the steady state analysis of Trabandt and Uhlig (2009). Of course, Laffer curves are actually complicated objects that move around with shocks to the economy, so the actual economic limit to taxation is unknown. On the spending side of the fiscal limit, most societies have made decisions about the minimal role they wish their governments to play, placing a lower bound on spending. At one extreme, some minimal level of spending is required just to maintain the government's infrastructure investments and meet interest payments on outstanding government debt.

In practice, the effective limit on tax rates lies well below the peak of the Laffer curve. Growing political clout of the tea party in the United States is a recent manifestation of Americans' intolerance for taxation, despite the fact that U.S. tax rates lie well below their Laffer curve peaks, according to Trabandt and Uhlig's calculations. Fiscal reforms underway in Europe, whether increases in retirement ages in France, reductions in government pensions in Greece, or tightening of unemployment compensation requirements in Sweden, can be understood as political responses in economies that are approaching their fiscal limits.

*Prepared for the IMF Annual Research Conference, November 4-5, 2010. We thank Pierre-Olivier Gourinchas and Ayhan Kose for helpful comments and Todd Walker for many useful conversations. The views expressed are those of the authors and do not reflect the position of Barclays Capital or its management.

${ }^{\dagger}$ Barclays Capital, U.S. Economics Research, 745 Seventh Ave, 4th Floor, New York, NY 10019; phone: (212) 526-3714; Troy.Davig@barclayscapital.com

$\ddagger$ Indiana University and NBER, 105 Wylie Hall, Bloomington, IN 47405; phone: (812) 855-9157; eleeper@indiana.edu 
Resistance to the reforms can place lower bounds on government spending programs. More generally, fiscal limits will be driven by the political processes which determine how averse societies are to high taxes and how much societies value government spending on both goods and services and social programs.

Evidently, fiscal limits are country-specific, depending on a country's economic and political arrangements, and time-varying, shifting with the economic and political shocks that hit the economy. Although the state dependence of fiscal limits is conceptually clear, it makes them difficult to measure and quantify. But those difficulties do not diminish the potentially central role that fiscal limits play in influencing macroeconomic policy choices, private expectations of monetary and fiscal policies, and economic outcomes.

In normal times, when government financing needs exhibit stable fluctuations, fiscal limits can be of little consequence for the macroeconomic impacts of monetary and fiscal policies. Even if policies do not immediately adjust to stabilize debt, people have good reason to believe that eventually stabilization will occur, just as it has in the past. By extension, this implies that in normal times expectations of fiscal policy are well anchored by past fiscal behavior. With only a few exceptions, normal times characterize conditions in most advanced economies up to now. But normal times are coming to a close.

Many advanced economies are heading into an era of fiscal stress. Populations are aging and governments have made substantially more promises of old-age benefits than they have provisions for financing those benefits. Table 1 reports the International Monetary Fund's (2009) calculations of the net present value of aging-related spending in several advanced economies. Averaged across the G-20 countries, spending promises exceed funding plans to the tune of 400 percent of GDP. In the United States alone, the long-term imbalance associated with Social Security and Medicare is $\$ 75$ trillion in present value [Gokhale and Smetters (2007)].

\begin{tabular}{lr}
\hline Country & $\begin{array}{r}\text { Aging-Related } \\
\text { Spending }\end{array}$ \\
\hline \hline Australia & 482 \\
Canada & 726 \\
France & 276 \\
Germany & 280 \\
Italy & 169 \\
Japan & 158 \\
Korea & 683 \\
Spain & 652 \\
United Kingdom & 335 \\
United States & 495 \\
Advanced G-20 Countries & 409 \\
\hline
\end{tabular}

Table 1: Net present value of impact on fiscal deficit of aging-related spending, in percent of GDP. Source: International Monetary Fund (2009).

In an era of fiscal stress, past policy behavior may be a poor guide to future behavior and, therefore, a weak reed on which to base policy expectations. When the stress is unresolved, 
fiscal expectations are unanchored and people are forced to speculate about future policy actions. Unanchored fiscal expectations can undermine the ability of monetary policy to control inflation and influence economic activity in the usual ways, as Leeper (2010a,b) emphasizes. Eusepi and Preston (2010) obtain similar implications for the efficacy of monetary policy in an environment in which agents are learning about the fiscal policy regime.

This paper models the era of fiscal stress as stemming from promised government transfers to private citizens, which are growing relentlessly as a share of GDP, just as they do in many countries' long-term projections that embed anticipated demographic shifts. In the model, the promised transfers initially are fully honored, being financed by new sales of government debt that bring forth higher future income taxes. As debt levels and tax rates rise, the population's tolerance for taxation declines and the probability of reaching the fiscal limit increases. At the limit a fixed tax rate is adopted and adjustments in taxes can no longer stabilize debt.

A probabilistic fiscal limit of this form reflects two features of the political economy of debt stabilization. First, even though the economy is well below the peak of the Laffer curve, meaning that it is feasible to raise revenues by increasing tax rates, the willingness of political leaders to do so declines as the electorate grows more disgruntled with high taxes. This feature reflects a key insight by Eaton and Gersovitz (1981) that a government's decision to honor its debt obligations is rarely about its ability to pay. ${ }^{1}$ Second, the likelihood of hitting the fiscal limit depends on economic conditions - the state of government indebtedness and tax rates - and on random political outcomes that may be more closely related to the electorate's reactions to fiscal decisions - street protests in the capital city, for examplethan to the fiscal decisions themselves. Uncertainty about future fiscal adjustments is a key characteristic of actual fiscal environments in advanced economies heading into an era of fiscal stress.

A rational expectations equilibrium with no outright government default requires that at the fiscal limit people must believe that policies will eventually adjust to stabilize debt. Davig, Leeper, and Walker $(2010,2011)$ posit that either transfers adjust so that delivered transfer payments are less than promised, while monetary policy targets inflation, or promised transfers continue to be honored, but monetary policy sacrifices inflation targeting in order to maintain the value of debt. Each of these regimes has either fiscal policy or monetary policy acting to stabilize debt.

In this paper we allow for those policy adjustments, but expand the set of post-fiscal limit policies to include a regime in which neither monetary nor fiscal policy stabilizes debt, at least temporarily. A temporary regime with unstable government debt is of practical relevance for a number of reasons. First, we have observed economies that go through periods in which debt grows rapidly and fears of "unsustainable" policies are raised. ${ }^{2}$ Second, this is a policy scenario that may well play out in coming years in economies that have difficulty consolidating fiscal policy on the heels of the large stimulus packages implemented in 2009 in response to the recession and financial crisis. As economies recover and inflation picks

\footnotetext{
${ }^{1} \mathrm{Bi}$ (2009) elaborates on this point in the context of sovereign debt default.

${ }^{2}$ Witness the concerns of many European governments in 2010. Davig and Leeper (2006) estimate that such a regime occurred in the United States in the early-to-mid 1980s, which was a period that inspired a cottage industry to "test" the government's intertemporal budget constraint [Hamilton and Flavin (1986), Davig (2005) and many others].
} 
up, central banks may shift back to their normal policies of aggressively fighting inflation well before fiscal consolidations are in place. We are already seeing this happen in Canada, Norway, and Sweden, which have begun to raise their policy interest rates. More hawkish monetary policies in the face of unresolved fiscal stress could easily produce triply active policies. ${ }^{3}$ Conventional models that do not allow for policy regime change cannot examine triply active policies and are silent about the macroeconomic consequences of this likely policy scenario. Third, in a period of unresolved, and unprecedented, fiscal stress, it is reasonable for economic decision makers to believe that a wide range of policy regimes are possible, with a regime in which no policy authority stabilizes debt just one of several possibilities.

The possibility of temporarily unstable government debt can have profound inflationary consequences in an economy with a probabilistic fiscal limit that incorporates the public's limited tolerance for taxation. Fiscal behavior can undermine the central bank's ability to control inflation and the central bank's loss of inflation control is not due to the bank's lack of resolve to fight inflation.

We also examine the inflationary consequences of news that discretely shifts the public's beliefs about the government's long-run fiscal situation. If that news reduces the expected path of primary surpluses, future inflation can be brought into the present, well before the news shows up in fiscal measures.

\section{Contacts with Literature}

In any dynamic economy monetary and fiscal policies have two tasks: to control inflation and to maintain the value of government debt. The conventional assignment, in which inflation is a monetary phenomenon, tasks monetary policy with controlling inflation and fiscal policy with maintaining the value of debt. This conventional assignment dates back at least to Friedman (1960) and is reflected in the modern new Keynesian models of Galí (2008) and Woodford (2003).

An alternative assignment of the two tasks is possible, however. Fiscal policy could be assigned to control inflation, leaving monetary policy to maintain the value of debt. This assignment delivers the fiscal theory of the price level associated with Leeper (1991), Sims (1994), Woodford (1995), and Cochrane (1999). American policies during and immediately after World War Two are a well-known example of this assignment: taxes were unable to keep pace with war spending, producing rapid increases in government debt issuance; the Fed pegged nominal interest rates to ensure high bond prices that helped finance the war effort.

Perhaps less appreciated is that policies in many countries during the past several years likely also fall into this category. After reducing policy interest rates to or near their zero lower bound, many central banks began unconventional operations that massively expanded their balance sheets. Coincident with the shift in monetary policy, fiscal authorities implemented large stimulus packages that sharply raised fiscal deficits, sometimes to unprecedented peacetime levels.

Some terminology can succinctly describe this policy behavior. A policy authority that is free to pursue its objectives is called "active," while an authority whose behavior is con-

\footnotetext{
${ }^{3}$ Norway and Sweden are not facing the fiscal stress that confronts many other countries. The numbers in table 1, however, suggest that Canada has substantial long-run fiscal imbalances.
} 
strained is termed "passive," following Leeper (1991). An active authority pays no attention to the state of government debt and is free to set its control variable as it sees fit. A passive authority responds to government debt shocks. Its behavior is constrained by private optimization and the active authority's actions. In the conventional assignment of tasks, monetary policy is "active" and controls inflation, while fiscal policy is "passive" and stabilizes debt. The alternative assignment reverses these: fiscal policy is "active" and free to pursue its objectives, such as output stabilization, while monetary policy "passively" maintains the value of government debt.

Because an active authority is not constrained by current budgetary conditions, it is free to choose a decision rule that depends on past, current, or expected future variables. A passive authority is constrained by consumer optimization and the active authority's actions, so it must generate sufficient primary surpluses to stabilize debt over time. Thus, the passive authority's decision rule necessarily depends on the current state of government debt, as summarized by current and past variables. ${ }^{4}$

This paper is a close cousin to Sargent and Wallace's (1981) unpleasant monetarist arithmetic, but with an unusual twist. Sargent and Wallace consider a setting in which the fiscal limit is couched as a maximum debt-GDP level. In the period before the limit, monetary and fiscal policies are both active, setting the money stock and the primary surplus exogenously. Government debt grows until it hits the limit at a known date $T$, at which point money growth becomes endogenous, determined by the need to service the debt level $b(T)$. Before the fiscal limit, policies are doubly active; after the limit, fiscal policy is active and monetary policy is passive, a regime that is an absorbing state. Long-run expectations of policies are pinned down by this absorbing state.

Our work turns this sequence of policy regimes on its head. In the period before the limit, tax policy passively raises rates in response to growing debt, while monetary policy actively targets inflation by following the Taylor principle. At the limit, tax rates are constant, so tax policy becomes active, but monetary and transfers policies continue to be active. This triply

\footnotetext{
${ }^{4}$ Viewing active policy as forward-looking and passive policy as backward-looking is consistent with the "rules versus authorities" debate [Simons (1936)]. Friedman (1948) argues against "discretionary action in response to cyclical movements" (p. 250) because it requires policy makers "to forecast accurately the economic changes that would occur in the absence of government action" (p. 255). In his 1948 proposal, however, Friedman does not oppose "automatic" responses of fiscal variables to fluctuations in economic activity. The model we use interprets the automatic behavior as passively setting policy instruments as a function of current and past variables, which does not require knowing the true processes generating the shocks. There are many other precedents for the active-passive taxonomy of policy behavior. Citing the rapid money growth in the early 60s, Samuelson (1967, p. 6) describes American policy in 1961-1965 as "a case of active fiscal policy which was coupled with or financed by a supporting monetary policy" [emphasis added]. In his view, monetary policy accommodates fiscal expansions to counteract the interest-rate increases that would crowd out investment. In this paper, monetary accommodation prevents deficit shocks from raising interest rates and producing an explosive path of government debt. Olivera (1970) and Black (1972) define an exogenous money stock as active monetary policy and an exogenous price level as requiring passive monetary policy. In Sargent's (1986) depiction of a Ricardian regime, the monetary authority is the "dominant player," while the fiscal authority "follows" and raises taxes as necessary to balance the budget. This is consistent with active monetary and passive fiscal policies. Sargent and Wallace's (1981) unpleasant monetarist arithmetic arises from a coordination scheme in which "fiscal policy dominates monetary policy" and "the monetary authority faces the constraints imposed by the demand for government bonds...." This corresponds to active fiscal and passive monetary behavior.
} 
active regime coincides with Sargent and Wallace's assumptions about policies before period $T$. Triply active policies are persistent, but transient in our setup. Each period policies can change instead to a mix of passive monetary and active transfers or a combination of active monetary and passive transfers. Eventually, though, the economy converges to an absorbing state in which monetary policy actively targets inflation and transfers passively adjust to stabilize debt.

Sargent and Wallace's result that, even in a monetarist economy, monetary policy may not be able to control inflation, plays off of their absorbing state in which monetary policy is passively constrained to meet the needs of fiscal policy. A Cagan (1956)-style money demand function can then bring that future loss of inflation control into the present. In contrast, we examine a situation in which the absorbing state is one in which monetary policy can perfectly control inflation and long-run expectations are anchored on this active monetary/passive transfers regime. Our economy is also in a regime with active monetary and passive tax policies in the period before the fiscal limit. Transient states that may be realized at the limit, before reaching the absorbing state, however, can undermine monetary policy's control of inflation in all periods before the absorbing state is realized.

Compared to Sargent and Wallace, our setup lays out substantially weaker conditions under which monetary policy may not be able to control inflation. Monetary control of inflation may be far more difficult than Sargent and Wallace describe.

It turns out that how the fiscal limit is modeled can matter a great deal for the model's implications. Leeper (2010a) examines an endowment economy in which at some known future date $T$, taxes hit their maximum and remain fixed. Before the limit, monetary policy actively targets inflation and taxes passively rise with debt; after the limit, monetary policy switches to passively pegging the short-term nominal interest rate, while taxes are constant at their limit. Policies in periods $t \geq T$ produce a fiscal theory of the price level equilibrium. In the absence of a fiscal limit, policies in periods $t<T$ would produce the conventional Taylor principle outcome in which monetary policy successfully targets inflation. The presence of a fiscal limit and forward-looking economic behavior, however, bring the fiscal theory equilibrium into the pre-limit period to produce some surprising results. Monetary policy can no longer control inflation, even in the pre-limit period. A stronger response of taxes to debt before period $T$ raises the volatility of the value of debt and of inflation. More hawkish monetary policy makes expected inflation more unhinged from the inflation target in the pre-limit period.

More elaborate models in which the timing of the fiscal limit is uncertain, as in Davig, Leeper, and Walker (2010, 2011), do not as strongly exhibit these seemingly perverse results. For example, stronger responses of taxes to debt temper the endogenously rising probability of the fiscal limit, postponing its impacts. Monetary policy continues to lose its ability to control actual and expected inflation, but the loss of control is more subtle.

\section{Monetary-Fiscal Policy Interactions and Inflation: A Primer}

Most macroeconomists have been weaned on Friedman's aphorism that "inflation is always and everywhere a monetary phenomenon," and most macroeconomic models build this perspective in as a necessary implication. Sargent and Wallace (1981) dramatically demonstrated that fiscal policy can be the driving force behind inflation, but even in their work 
inflation is determined entirely by the interaction of supply and demand for money: in equilibrium, inflation equals money growth.

Recent work under the rubric of the fiscal theory of the price level broadens this perspective on the determination of inflation by considering environments in which the government issues nominal debt. ${ }^{5}$ The theory points to circumstances in which inflation is driven by an equilibrium condition that connects the value of that debt to the expected discounted value of primary surpluses and seigniorage.

More generally, inflation is always determined by the interaction of monetary and fiscal policies. There are special cases in which it appears to be a monetary phenomenon and other cases in which it seems to be a fiscal phenomenon. This section develops a simple framework that makes this general point.

The model that follows ascribes simple parametric interpretations to active and passive monetary and fiscal policy behavior, defined in section 2, and characterizes the nature of inflation determination in the two policy mixes that allow policies to control inflation and stabilize government debt.

3.1 The Model To streamline the algebra, we assume that there are no real effects from monetary and fiscal actions and abstract from any monetary frictions by assuming that real money balances are a negligible share of GDP. ${ }^{6}$ These assumptions make the model a constant endowment economy that is at the cashless limit.

The economy consists of a representative household, a monetary authority, and a fiscal authority. The household pays lump-sum taxes, $\tau_{t}$, receives lump-sum transfers, $z_{t}$, and holds one-period nominal bonds paying gross risk-free nominal interest $R_{t}$. Consumption and bonds, $\left\{c_{t}, B_{t}\right\}$, are chosen to maximize

$$
E_{0} \sum_{t=0}^{\infty} \beta^{t} u\left(c_{t}\right)
$$

subject to the budget constraint

$$
c_{t}+B_{t} / P_{t}+\tau_{t}=y_{t}+z_{t}+R_{t-1} B_{t-1} / P_{t}
$$

with $R_{-1} B_{-1}>0$ given. Government purchases are zero in each period so that goods market clearing implies $c_{t}=y_{t}=y$. In equilibrium the household's consumption/saving decision produces a simple Fisher relation that links the nominal interest rate to the (constant) real interest rate, $1 / \beta$, and the expected inflation rate, $P_{t} / P_{t+1}$

$$
\frac{1}{R_{t}}=\beta E_{t}\left(\frac{P_{t}}{P_{t+1}}\right)
$$

\footnotetext{
${ }^{5}$ In advanced economies, the vast majority of government debt is nominal and denominated in home currency. In the United States, 90 percent is nominal; in the United Kingdom, 80 percent is; nominal debt constitutes over 90 percent of government debt in Australia, Canada, New Zealand, and Sweden; most European Monetary Union members' debt is nominal; all but a tiny fraction of Japanese government bonds are nominal.

${ }^{6}$ The model setup is similar to Leeper (1991), Sims (1994), and Woodford (2001). More realistic environments have been studied elsewhere [Woodford (1998), Davig and Leeper (2006, 2011), Sims (2011)].
} 
where $\beta \in(0,1)$ is the household's discount factor.

Monetary policy adjusts the short-term nominal interest rate to target inflation at $\pi^{*}$

$$
R_{t}^{-1}=R^{*-1}+\alpha\left(\frac{P_{t-1}}{P_{t}}-\frac{1}{\pi^{*}}\right)
$$

More hawkish policies set $\alpha$ larger and reduce fluctuations of inflation around target.

Fiscal policy attempts to target the real value of government debt (or the debt-GDP ratio) at $b^{*}$ by adjusting taxes in response to the state of government debt

$$
\tau_{t}=\tau^{*}+\gamma\left(\frac{B_{t-1}}{P_{t-1}}-b^{*}\right)
$$

Government transfer payments to the household are the sole source of uncertainty in the model. Additional sources of uncertainty could be introduced, but they would not alter the basic story of inflation determination. We imagine that transfers evolve exogenously according to a known stochastic process. The growth rate of transfers is permitted to be positive, but it must be bounded to ensure that transfers do not grow faster than the real interest rate.

The government's flow budget constraint is

$$
\frac{B_{t}}{P_{t}}+\tau_{t}=z_{t}+\frac{R_{t-1} B_{t-1}}{P_{t}}
$$

so any shortfall in revenues over transfers and debt service is financed by new bond sales.

The household behaves rationally and takes account of the actual policy behavior - rules (4) and (5) - and of the evolution of transfers to form rational expectations over future prices, transfers, and taxes.

3.2 Regime M: Active Monetary/Passive Fiscal Policies The first policy mix is familiar to most macroeconomists and accords well with how many central bankers perceive their behavior. We label this "Regime M." Regime M emerges when the central bank aggressively targets inflation by raising the nominal interest rate sharply in response to incipient inflation $(\alpha>1)$ and fiscal policy reacts to higher debt by raising taxes enough to achieve the debt target $(\gamma>r=1 / \beta-1)$. This combination is active monetary policy and passive fiscal policy.

The equilibrium in this regime is obtained by solving the difference equation in inflation produced by combining the Fisher equation, (3), with the monetary policy rule, (4), to yield

$$
\frac{\beta}{\alpha} E_{t}\left(\frac{P_{t}}{P_{t+1}}-\frac{1}{\pi^{*}}\right)=\frac{P_{t-1}}{P_{t}}-\frac{1}{\pi^{*}}
$$

The solution is that inflation always equals its target, as does expected inflation. ${ }^{7}$

$$
\pi_{t}=\pi^{*}
$$

\footnotetext{
${ }^{7}$ Technically, there are many solutions to (7), where all but the solution in (8) have inflation diverging from target without bound [see Obstfeld and Rogoff (1983), Sims (1994), and Cochrane (2007) for further discussion].
} 
The stabilization of debt by tax policy can be seen from combining the tax rule, (5), with the government's budget constraint, (6), and taking expectations to obtain

$$
E_{t-1}\left(\frac{B_{t}}{P_{t}}-b^{*}\right)=E_{t-1}\left(z_{t}-z^{*}\right)+\left(\beta^{-1}-\gamma\right)\left(\frac{B_{t-1}}{P_{t-1}}-b^{*}\right)
$$

Because $\beta^{-1}-\gamma<1$, higher debt brings forth the expectation of higher taxes, so (9) describes how debt is expected to return to its target, $b^{*}$, following a shock to transfers, $z_{t}$. Tax policy, through the choice of $\gamma$, stabilizes debt in the face of disturbances that move debt away from $b^{*}$. A higher value of $\gamma$ in the tax rule adjusts taxes more aggressively and retires debt back to target more rapidly.

3.3 Regime F: Passive Monetary/Active Fiscal Policies Regime F combines active tax policy, $0 \leq \gamma<1 / \beta-1$, with passive monetary policy, $0 \leq \alpha<1 / \beta$. This policy mix delivers a fiscal theory of the price level.

We focus on a particular policy mix that yields clean economic interpretations: the nominal interest rate is set independently of inflation, $\alpha=0$ and $R_{t}^{-1}=R^{*-1} \geq 1$, and taxes are set independently of debt, $\gamma=0$ and $\tau_{t}=\tau^{*}>0$. These policy specifications might seem extreme and special, but the qualitative points that emerge generalize to other specifications of passive monetary/active tax policies.

One result pops out immediately. Applying the pegged nominal interest rate policy to the Fisher relation, (3), yields

$$
E_{t}\left(\frac{P_{t}}{P_{t+1}}\right)=\frac{1}{\beta R^{*}}=\frac{1}{\pi^{*}}
$$

so expected inflation is anchored on the inflation target, an outcome that is perfectly consistent with one aim of inflation-targeting central banks. It turns out, however, that another aim of inflation targeters - stabilization of actual inflation - which can be achieved by active monetary/passive fiscal policy, is no longer attainable.

Impose the active tax rule on the intertemporal equilibrium condition, (11), ${ }^{8}$

$$
\frac{B_{t}}{P_{t}}=\left(\frac{\beta}{1-\beta}\right) \tau^{*}-E_{t} \sum_{j=1}^{\infty} \beta^{j} z_{t+j}
$$

The value of government debt at $t$ (or the debt-output ratio) is completely determined by tax and transfers policies expected in the future. A higher fixed level of taxes, $\tau^{*}$, or a lower expected path of transfers, $E_{t} \sum_{j=1}^{\infty} \beta^{j} z_{t+j}$, raises the value of debt.

\footnotetext{
${ }^{8}$ Expression (11) is derived in several steps. Write the government budget constraint, (6), at time $t+1$, impose the tax rule that $\tau_{t}=\tau^{*}$, take expectations conditional on information at time $t$, and impose the Fisher equation, (3), to replace $E_{t} R_{t} / \pi_{t+1}$ with $1 / \beta$. Iterate forward on the resulting expression and impose the transversality condition for debt that ensures the agent's maximization problem is solved, $\lim _{T \rightarrow \infty} E_{t} \beta^{T} b_{T}=0$, to obtain (11). By imposing market clearing and private optimizing behavior on the government's budget constraint, we arrive at an equilibrium condition, not a constraint on government behavior.
} 
Combine the government's flow constraint, (6), with (11) to solve for the equilibrium price level from

$$
\frac{R^{*} B_{t-1}}{P_{t}}=\left(\frac{1}{1-\beta}\right) \tau^{*}-E_{t} \sum_{j=0}^{\infty} \beta^{j} z_{t+j}
$$

At time $t$, the numerator of the left side of this expression is predetermined, representing the nominal value of household wealth carried into period $t$. The right side is the expected present value of primary fiscal surpluses from date $t$ on, which is exogenous. So long as $R^{*} B_{t-1}>0$ and the present value of revenues exceeds the present value of transfers, a condition that must hold if government debt has positive value, expression (12) delivers a unique $P_{t}>0 .^{9}$

Using the solution for the price level in (12) to compute expected inflation, it is straightforward to show that $\beta E_{t}\left(P_{t} / P_{t+1}\right)=1 / R^{*}$, as required by the Fisher relation and monetary policy behavior. This observation leads to a sharp dichotomy between the roles of monetary and fiscal policy in price-level determination: monetary policy alone appears to determine expected inflation by choosing the level at which to peg the nominal interest rate, $R^{*-1}$, while conditional on that choice, fiscal variables appear to determine realized inflation. This is the essence of the fiscal theory of the price level.

3.4 Discussion Regime M-the usual assignment of policy responsibilities in which monetary policy controls inflation - relies on fiscal policy to ensure that any increase in government debt creates the expectation of higher taxes in the future. ${ }^{10}$ Those higher taxes are just sufficient to gradually retire debt back to its target level, eliminating any wealth effect from the debt expansion and, therefore, any pressure on inflation to rise. This Ricardian fiscal adjustment is critical for monetary policy to successfully control inflation. For example, if the central bank were to contract policy by exogenously increasing the interest rate via an open-market sale of government bonds to the public, this must generate higher expected taxes for the monetary contraction to reduce inflation. If taxes were not expected to rise, higher bond holdings would raise the public's nominal wealth, which would increase nominal demand and inflation.

Higher inflation from a monetary contraction is one of several unusual implications of Regime F. Equilibrium inflation in Regime F can be derived by combining (11) with (6) to yield

$$
\pi_{t}=\frac{R^{*} B_{t-1} / P_{t-1}}{\frac{1}{1-\beta} \tau^{*}-E_{t} \sum_{j=0}^{\infty} \beta^{j} z_{t+j}}
$$

\footnotetext{
${ }^{9}$ We have done nothing mystical here, despite what some critics claim [for example, Buiter (2002) or McCallum (2001)]. In particular, the government is not assumed to behave in a manner that violates its budget constraint [see footnote 8]. Unlike competitive households, the government is not required to choose sequences of control variables that are consistent with its budget constraint for all possible price sequences. Indeed, for a central bank to target inflation, it cannot be choosing its policy instrument to be consistent with any sequence of the price level; doing so would produce an indeterminate equilibrium. Identical reasoning applies to the fiscal authority: the value of a dollar of debt- $1 / P_{t}$ - depends on expectations about fiscal decisions in the future; expectations, in turn, are determined by the tax rule the fiscal authority announces. The fiscal authority credibly commits to its tax rule and, given the process for transfers, this determines the backing of government debt and, therefore, its market value.

${ }^{10}$ In this model, we force taxes to adjust, but more generally Regime M requires that higher debt creates higher expected primary surpluses.
} 
This equilibrium echoes Sargent and Wallace's (1981) unpleasant arithmetic result: if the central bank chooses a higher pegged nominal interest rate for $R^{*}$, inflation rises. Unpleasantness arises for very different reasons in the fiscal theory. Higher $R^{*}$ raises nominal interest payments that the agents receives on holdings of government debt. With taxes fixed at $\tau^{*}$, higher interest payments do not portend higher future taxes, so the agent feels richer and tries to raise her consumption path. When output is fixed, higher nominal demand simply raises inflation.

Expression (13) also makes clear the sense in which inflation is a fiscal phenomenon in Regime F. News that transfer payments will rise or that the fixed level of taxes will fall, both raise the agent's perception of her wealth-because there will be no offsetting fiscal adjustments in the future - and raises her consumption demand and, therefore, inflation.

In Regime F, monetary policy loses its ability to control inflation because fiscal policy is unable or unwilling to adjust future surpluses to sustain government debt. Instead, the value of that debt must adjust to be consistent with expected surpluses and that adjustment occurs through changes in the price level that alter the value of debt. Monetary policy is nevertheless playing a critical role in allowing the equilibrium to hang together. Suppose that the central bank were to try to counteract the fiscally-induced rise in inflation by sharply raising the nominal interest rate (as it would if it were behaving actively). This would increase nominal interest payments on debt and, because fiscal policy is active, increase nominal demand and inflation. Higher inflation would trigger still more increases in nominal interest rates, nominal demand, and inflation: the process is unstable; debt would grow exponentially and lose its value. Doubly active policies, if they were to persist, can produce explosive inflation, as Sims (2011) shows.

Fiscal behavior in Regime $\mathrm{F}$ leads to a natural interpretation of what happens at a fiscal limit: primary surpluses no longer adjust to stabilize debt. At the fiscal limit, one of two outcomes are possible. Either monetary policy will switch to being passive, as it does in Regime F, or it continues to be active and neither monetary nor fiscal policy stabilizes debt. Permanently doubly active policies that generate explosive growth in real debt cannot happen if government debt is to retain its value. But temporarily an economy can visit a regime in which debt is unstable, so long as bond holders expect that eventually either monetary or fiscal policy will revert to passive behavior that stabilizes debt's value.

\section{Modeling Fiscal Limits}

We examine two general methods to model the probability of hitting the fiscal limit-one exogenous and the other state-dependent - and variations within each method. Let $\tau_{t}$ denote the proportional tax rate on income and let $\tau^{\max }$ denote the value of the tax rate at the fiscal limit. When the economy hits the fiscal limit, monetary and fiscal policies change regime and in the period before the limit is triggered, agents' expectations are driven, in part, by beliefs about those post-limit policies.

4.1 Exogenous Limits One simple method to set an exogenous fiscal limit posits a fixed probability, $p_{L}$, each period that the economy will hit the limit. At the limit, $\tau_{t}=\tau^{\max }$ forever. Because $p_{L}$ is independent both of the state of the economy and of time, this method does not generate time-varying expectations, as does the alternative method discussed below. 
Davig, Leeper, and Walker (2010) and Leeper (2010a) assume that at some known date in the future, $T$, the fiscal limit kicks in and the tax rate becomes permanently set at $\tau^{\max }$. As mentioned above, this method generates some unusual implications. It also produces timevarying expectations that are more volatile the farther into the future $T$ is; as $T$ approaches, the equilibrium converges to the post-limit equilibrium.

The fixed probability of hitting the limit each period generalizes the known $T$ limit. Based on the probability, $1-p_{L}$, the pre-limit regime has expected duration $\left(1-p_{L}\right)^{-1}$ and based on that duration, there is some expected $T$ date.

4.2 Endogenous Limits Of more economic interest is fiscal limits that are triggered by recent fiscal policy actions. It is not difficult to imagine the populace reacting against repeated increases in tax rates brought on by growing government debt. One way to model this, which retains the stochastic nature, is with a logistic function. Let $p_{L, t}$ be the probability of hitting the fiscal limit at date $t$, where $p_{L, t}$ obeys

$$
p_{L, t}=1-\frac{\exp \left(\eta_{0}-\eta_{1}\left(\tau_{t-1}-\tau^{*}\right)\right.}{1+\exp \left(\eta_{0}-\eta_{1}\left(\tau_{t-1}-\tau^{*}\right)\right.}
$$

where $\tau^{*}$ is some reference tax rate and both $\eta_{0}$ and $\eta_{1}$ are positive parameters. When coupled with a tax rule such as

$$
\tau_{t}=\tau^{*}+\gamma\left(b_{t-1}-b^{*}\right)
$$

expression (14) means that as the debt-GDP ratio, $b_{t}$, rises above a reference ratio, $b^{*}$, the tax rate rises and so, too, does the probability of reaching the fiscal limit. If the fiscal limit is hit in period $t$,

$$
\tau_{s}=\tau^{\max } \quad \text { for all } s \geq t
$$

The parameters $\left(\eta_{0}, \eta_{1}\right)$ in (14) determine the initial probability and the speed at which the probability rises with taxes. Alternative settings of these parameters can imply very different fiscal limit processes, ranging from ones in which the economy is expected to hit the limit soon to ones in which the likely date of the limit is quite is remote. The paper will characterize how equilibrium outcomes vary with these parameters. Figure 1 depicts one logistic function whose impacts we derive in section 7 below.

\section{Model And Solution Method}

We use the canonical new Keynesian model with elastic labor supply and a fixed capital stock. Prices are perfectly flexible so monetary policy cannot affect real interest rates. We expand the textbook model of, say, Woodford (2003) or Galí (2008), by adding nominal government bonds, a distorting tax, and the possibility of monetary and fiscal policy regime change.

We modify the model in Davig and Leeper (2006) in the following ways: add a distorting proportional labor tax rate; introduce a fiscal limit along the lines that section 4 sketches; allow lump-sum transfers initially to follow a stationary stochastic process, which then switches to a non-stationary process with some fixed probability; posit how monetary and fiscal policies adjust at the fiscal limit. 


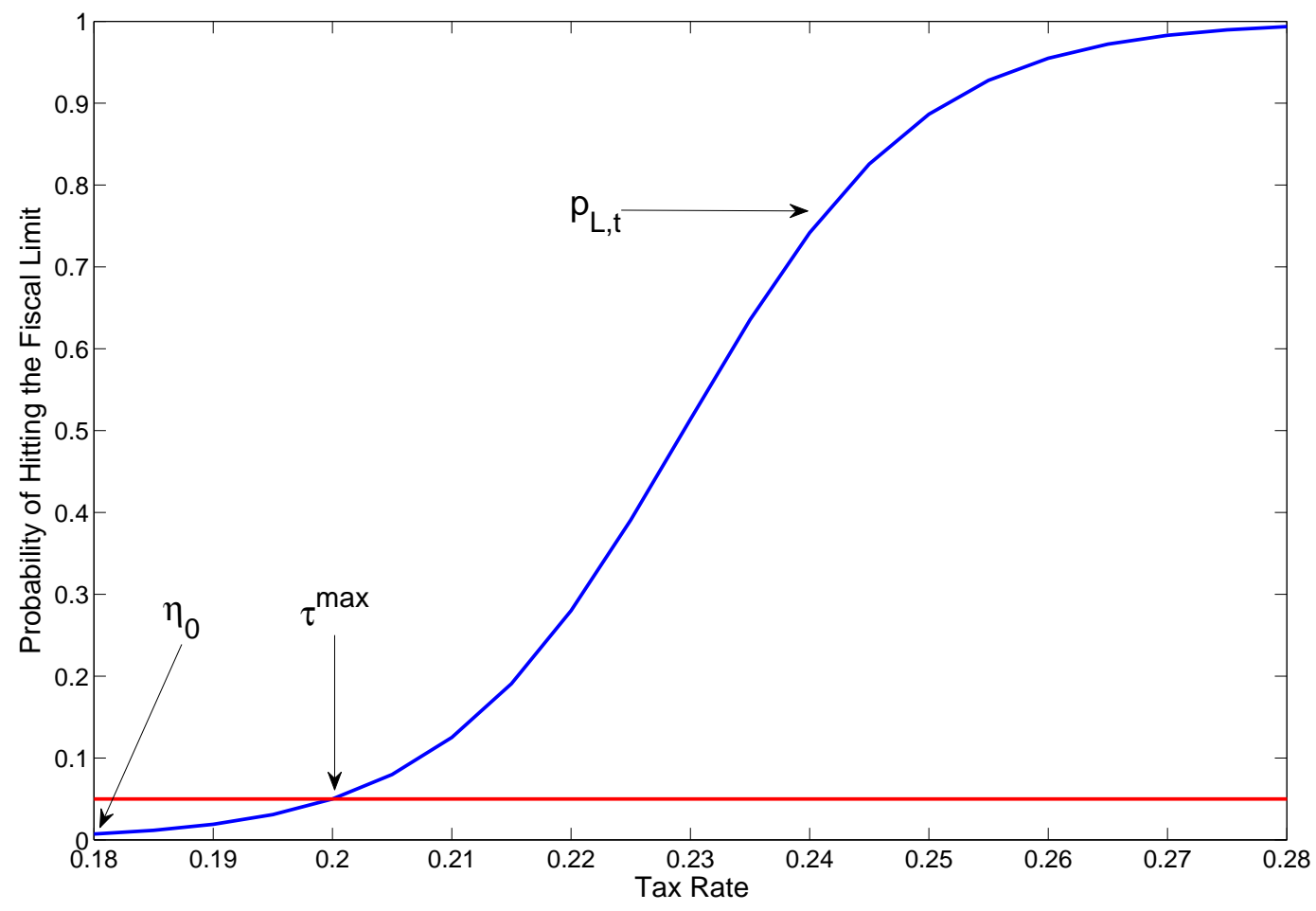

Figure 1: Probability of hitting the fiscal limit as a function of the tax rate. Logistic function in (14) with $\eta_{0}$ and $\eta_{1}$ set so that the initial probability is 2 percent and rises to 20 percent by the year 2075 .

5.1 Households The representative household optimizes over $\left\{C_{t}, N_{t}, M_{t}, B_{t}\right\}$ to maximize

$$
E_{t} \sum_{i=0}^{\infty} \beta^{i}\left[\frac{C_{t+i}^{1-\sigma}}{1-\sigma}-\chi \frac{N_{t+i}^{1+\eta}}{1+\eta}+\delta \frac{\left(M_{t+i} / P_{t+i}\right)^{1-\kappa}}{1-\kappa}\right]
$$

with $0<\beta<1, \sigma>0, \eta>0, \kappa>0, \chi>0$ and $\delta>0 . C_{t}=\left[\int_{0}^{1} c_{t}(j)^{\frac{\theta-1}{\theta}} d j\right]^{\frac{\theta}{\theta-1}}$ is a composite consumption good consisting of differentiated goods $c_{j t}$, where $\theta>1$ is the elasticity of substitution across goods. $N_{t}$ is labor and $\left(M_{t} / P_{t}\right)$ denote real money balances.

The household's budget constraint is

$$
C_{t}+\frac{M_{t}}{P_{t}}+\frac{B_{t}}{P_{t}} \leq\left(1-\tau_{t}\right)\left(\frac{W_{t}}{P_{t}}\right) N_{t}+\frac{M_{t-1}}{P_{t}}+\frac{\left(1+R_{t-1}\right) B_{t-1}}{P_{t}}+\Pi_{t}+\lambda_{t} z_{t}
$$

where $\tau_{t}$ is a distorting tax levied on labor income, $B_{t}$ is one-period nominal bond holdings, $W_{t}$ is the nominal wage rate, $1+R_{t-1}$ is the risk-free nominal interest rate between $t-1$ and $t, \Pi_{t}$ are profits from intermediate-goods producers, and $\lambda_{t} z_{t}$ are delivered lump-sum transfers. The household maximizes (17) subject to (18), yielding

$$
\chi \frac{N_{t}^{\eta}}{C_{t}^{-\sigma}}=\left(1-\tau_{t}\right) \frac{W_{t}}{P_{t}}
$$




$$
1=\beta E_{t}\left[\left(1+R_{t}\right) \frac{P_{t}}{P_{t+1}}\left(\frac{C_{t}}{C_{t+1}}\right)^{\sigma}\right]
$$

and the money demand function

$$
\frac{M_{t}}{P_{t}}=\left[\delta C_{t}^{\sigma}\left(\frac{1+R_{t}}{R_{t}}\right)\right]^{1 / \kappa}
$$

Necessary and sufficient conditions for household optimization require that (19)-(21) hold in every period. In addition, the household's budget constraint must bind, the present value of the households' expected expenditures must be bounded, and the transversality condition

$$
\lim _{T \rightarrow \infty} E_{t}\left[q_{t, T} \frac{A_{T}}{P_{T}}\right]=0
$$

must hold, where $A_{t}=B_{t}+M_{t}$ and $q_{t, T}$ is the real stochastic discount factor obtained from the household's Euler equation, (20).

5.2 Firms A continuum of monopolistically competitive firms indexed by $j$ produces goods according to

$$
y_{j t}=Z N_{j t}
$$

where $Z$ is an aggregate measure of technology that is common across all firms and constant. A final goods producing firm purchases intermediate inputs at nominal prices $P_{t}(j)$ and produces the final composite good by combining them using the constant-returns-to-scale technology, $Y_{t}=\left[\int_{0}^{1} y_{t}(j)^{\frac{\theta-1}{\theta}} d j\right]^{\frac{\theta}{\theta-1}}$. Profit maximization by the final-goods producing firm yields a demand for each intermediate good given by

$$
y_{t}(j)=\left(\frac{P_{t}(j)}{P_{t}}\right)^{-\theta} Y_{t}
$$

where $P_{t} \equiv\left[\int_{0}^{1} p_{j t}^{1-\theta} d j\right]^{\frac{1}{1-\theta}}$.

Each monopolistically competitive intermediate-goods producing firm chooses price $P_{t}(j)$ to maximize the expected present-value of profits

$$
E_{t} \sum_{s=0}^{\infty} \beta^{s} \lambda_{t+s} \frac{D_{t+s}(j)}{P_{t+s}}
$$

where $\lambda_{t+s}$ is the owner's marginal utility and $D_{t}(j)$ are nominal profits of firm $j$. Real profits are

$$
\frac{D_{t}(j)}{P_{t}}=\left(\frac{P_{t}(j)}{P_{t}}\right) y_{t}(j)-\Psi_{t}(j) y_{t}(j)
$$

where $\Psi_{t}(j)$ is real marginal cost.

In a symmetric equilibrium, every intermediate goods producing firm faces the same marginal costs, $\Psi_{t}$, and aggregate demand, $Y_{t}$, so the pricing decision is the same for every firm, implying $P_{t}(j)=P_{t}$. In steady-state, marginal costs are $\Psi=(\theta-1) / \theta$, where $\Psi^{-1}=$ $\mu$ and $\mu$ is the steady-state markup of price over marginal cost.

The aggregate resource constraint is

$$
C_{t}+G_{t}=Y_{t}
$$


5.3 Policy Specification The government finances a constant amount of government purchases, $G$, and actual transfers, $\lambda_{t} z_{t}$, with distorting taxes on labor, money creation, and the sale of one-period nominal bonds. The government's flow budget constraint is

$$
\frac{B_{t}}{P_{t}}+\frac{M_{t}}{P_{t}}+\tau_{t}\left(\frac{W_{t}}{P_{t}} N_{t}\right)=G_{t}+\lambda_{t} z_{t}+\frac{R_{t-1} B_{t-1}}{P_{t}}+\frac{M_{t-1}}{P_{t}}
$$

In order to capture the non-stationary behavior of the transfers process, we assume transfers follow a Markov switching process with two states,

$$
z_{t}= \begin{cases}\left(1-\rho_{z}\right) \bar{z}+\rho_{z} z_{t-1}+\varepsilon_{t} & \text { for } S_{z, t}=1 \\ \mu z_{t-1}+\varepsilon_{t} & \text { for } S_{z, t}=2\end{cases}
$$

where $z_{t}=Z_{t} / P_{t},\left|\rho_{z}\right|<1, \mu>1, \mu \beta<1, \varepsilon_{t} \sim N\left(0, \sigma_{z}^{2}\right)$. Regime 2 is characterized by $\mu>1$ and $\beta \mu<1$, which allows the transfers process to be non-stationary, but squaresummable in discounted expectation. We use this process to capture the upward trend in promised transfers that many countries are facing. The regimes, $S_{z t}$, follow a Markov chain that evolves according to

$$
\Pi_{z}=\left[\begin{array}{cc}
1-p_{z} & p_{z} \\
0 & 1
\end{array}\right]
$$

where the regime with exploding promised transfers is an absorbing state. The expected number of years until the switch from the stationary to nonstationary regime is $\left(1-p_{z}\right)^{-1}$.

The stationary process has expected duration of about five years. This assumption is designed to mimic the expected growth in transfers as a share of GDP that the Congressional Budget Office annually reports in its long-term projections [Congressional Budget Office (2010)] and are projected in many other advanced economies as well. We interpret this transfers process for $z_{t}$ as "promised" transfers. "Delivered" transfers, $\lambda_{t} z_{t}$, may be less than promised due to entitlements reform.

Exponential growth in transfers is initially financed by new debt issuance, which is backed by increasing tax rates. But there is a fiscal limit to the amount of debt that can be financed through tax increases. This is due to either reaching the peak of the Laffer curve or to political resistance to tax hikes. We model this as setting $\tau_{t}=\tau^{\max }$ for $t \geq T$, where $T$ is the random date at which the economy hits the fiscal limit. Tax policy sets rates according to

$$
\tau_{t}= \begin{cases}\tau^{*}+\gamma\left(\frac{B_{t-1}}{P_{t-1}}-b^{*}\right) & \text { for } S_{\tau, t}=1, t<T(\text { Below Fiscal Limit }) \\ \tau^{\max } & \text { for } S_{\tau, t}=2, t \geq T \text { (Fiscal Limit) }\end{cases}
$$

where $b^{*}$ is the target debt-output ratio and $\tau^{*}$ is the steady-state tax rate.

Before the economy hits the fiscal limit, $\gamma>0$ is large enough to ensure that taxes respond sufficiently strongly to higher debt to cover real debt service plus some of the newly issued principal. With stationary transfers, this passive fiscal stance would stabilize debt. After the fiscal limit, tax rates are fixed and, in the absence of other policy adjustments, policy is unsustainable as debt would grow exponentially as a share of the economy. 
As in Davig, Leeper, and Walker $(2010,2011)$, we assume that the probability of hitting the fiscal limit, $p_{L t}$, follows a logistic function

$$
p_{L, t}=1-\frac{\exp \left(\eta_{0}-\eta_{1}\left(\tau_{t-1}-\tau^{*}\right)\right)}{1+\exp \left(\eta_{0}-\eta_{1}\left(\tau_{t-1}-\tau^{*}\right)\right)},
$$

where $\eta_{1}>0$, so the probability of hitting the fiscal limit is increasing in taxes. Because in the period leading up to the fiscal limit taxes respond passively to government debt, as (31) describes, the probability of hitting the fiscal limit increases with debt. Households are aware of the maximum tax rate, $\tau^{\max }$, but the precise timing of when that rate takes effect is uncertain.

Monetary policy is conventional in that it sets the short-term nominal interest rate in response to deviations of inflation from its target

$$
R_{t}=\bar{R}+\alpha\left(\pi_{t}-\pi^{*}\right)
$$

where $\pi^{*}$ is the target inflation rate. Monetary policy is active when $\alpha>1 / \beta$, so policy satisfies the Taylor principle. We label the active regime as $S_{m, t}=1$. Policy is passive when $0 \leq \alpha<1 / \beta,\left(S_{m, t}=2\right)$.

Figure 2 displays the evolution of the economy. The economy begins with stationary transfers, passive fiscal and active monetary policy. With probability $p_{z}$, the transfers process becomes non-stationary, $S_{z}=2$. The economy reaches the fiscal limit with probability $p_{L}$, tax policy becomes active $\left(S_{\tau}=2\right)$ and monetary and transfers policies continue to remain active. This regime captures a period of "gridlock" where monetary policy will not concede its inflation target, yet fiscal policy cannot raise taxes or reduce transfers to stabilize government debt. In a model with fixed policy regimes and growing transfers, triply active policies are not possible. Debt explodes, violating the transversality condition on government debt. Households would not hold debt, so no equilibrium exists. In the current setting, however, the triply active regime is expected to be only temporary, since households expect a transition to a policy regime that will stabilize debt.

The following transition matrix describes the complete progression of regimes from the figure

$$
\Pi_{T}=\left[\begin{array}{ccccc}
1-p_{Z} & p_{Z} & 0 & 0 & 0 \\
0 & p_{L} & 1-p_{L} & 0 & 0 \\
0 & 0 & p_{22} & p_{23} & p_{24} \\
0 & 0 & 0 & p_{33} & 1-p_{33} \\
0 & 0 & 0 & 0 & 1
\end{array}\right]
$$

where $p_{i i}$ is the probability of remaining in regime $i$. The first column of (34) applies to the stationary transfers process and the remaining four columns to the non-stationary transfers process. In the triply active regime, debt grows rapidly, as shown below, and households place a constant probability on moving to either a monetary regime that sacrifices its inflation target $\left(p_{23}\right)$ or a fiscal regime that reneges on promised transfers $\left(p_{24}\right)$. Eventually, however, policy moves to an absorbing state where debt and actual transfers are stabilized by the fiscal authority reneging on promised transfers. 


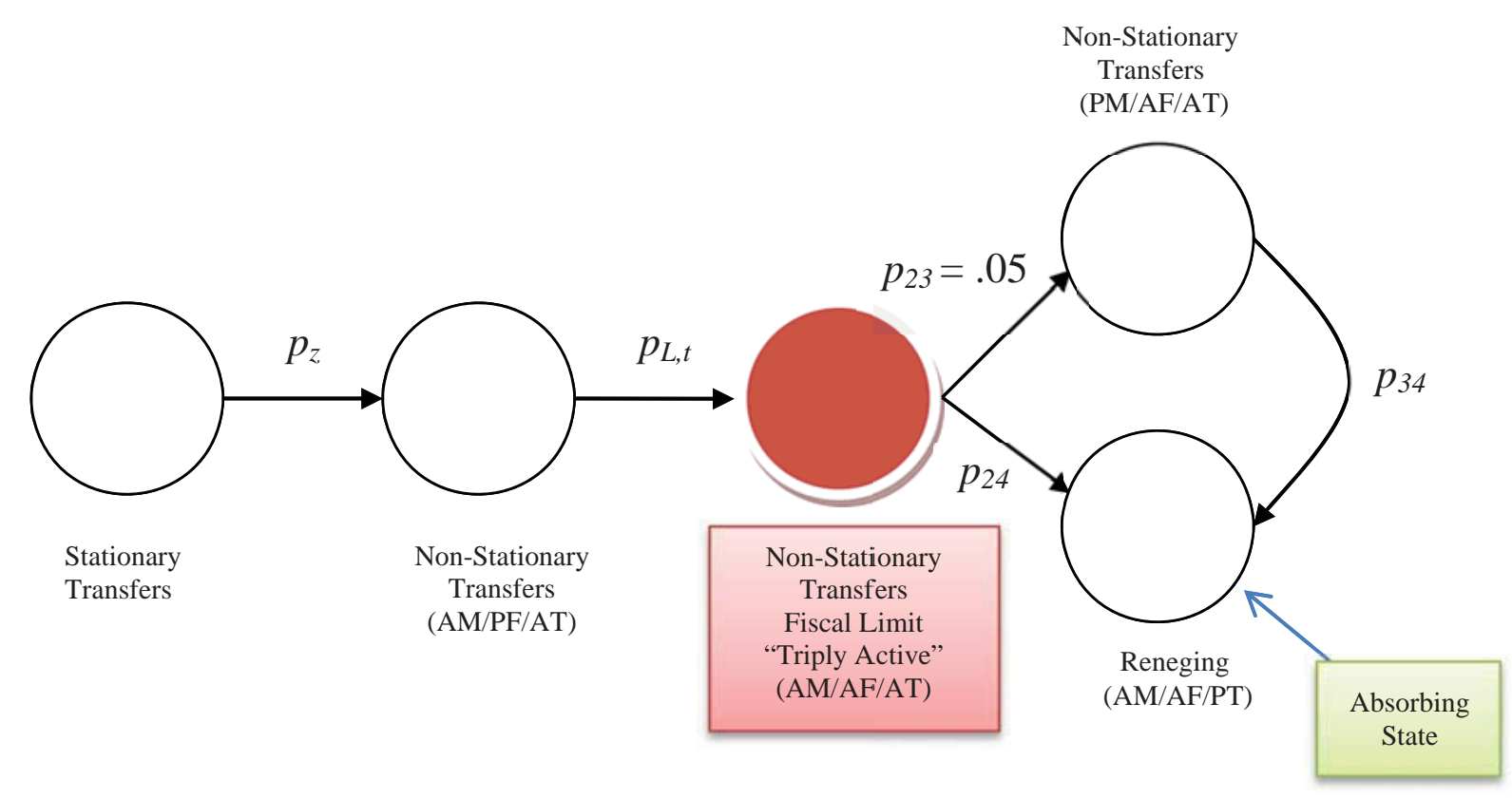

Figure 2: Evolution of policy regimes. $p_{Z}$ : probability of non-stationary transfers process; $p_{L, t}$ : probability of fiscal limit; AM: active monetary policy; PF: passive fiscal policy; AT: active transfers policy; PM: passive monetary policy; AF: active fiscal policy; PT: passive transfers policy.

5.4 Solution Method We solve the model numerically using the monotone map method described in Davig and Leeper (2006). Further details are provided in Davig, Leeper, and Walker (2010).

\section{Calibration}

The parameters over preferences, technology and price adjustment are consistent with the values in Rotemberg and Woodford (1997) and Woodford (2003). We calibrate the model at an annual frequency because the purpose of the model is to study the impact of fiscal policy over a relatively long horizon. Intermediate-goods producing firms markup the price of their good by 15 percent over marginal cost, so $\mu=\theta(1-\theta)^{-1}=1.15$. Prices are flexible, which is not unreasonable in an annual model. The annual real interest rate is set to 2.5 percent, with $\beta=.975$. Preferences over consumption and leisure are logarithmic, $\sigma=1$ and $\eta=1$. We set $\chi$ so the steady state share of time spent in employment is 0.2 . For real money balances, we set $\delta$ so velocity in the deterministic steady state, defined as $c P / M$, corresponds to the average U.S. monetary base velocity at $2.4 .{ }^{11}$ The interest elasticity of real money balances, $\kappa$, is set to 2.6 , which is consistent with Chari, Kehoe, and McGrattan (2000).

Average federal government purchases are a constant 8 percent share of output. In the regime with stationary transfers, $z^{*}$ is calibrated so steady state transfers are 9 percent of output. We also allow a small, but persistent, stochastic variation in the stationary transfers

\footnotetext{
${ }^{11}$ See Davig and Leeper (2006) for further details.
} 
process, $\rho_{Z}=.9$. Monetary policy is active in the regime with stationary transfers, where the reaction of the nominal interest rate to inflation obeys the Taylor principle, so $\alpha=1.5$. Fiscal policy is passive in the regime with stationary transfers with $\gamma=.1$. The inflation target, $\pi^{*}$, is set to 2 percent and the initial steady state debt-output ratio in the regime with stationary transfers is set to roughly 0.45 , which implies that the initial average tax rate is .198 (i.e. $\tau^{*}=.2$ ). This value is consistent with historical average tax rates in the United States. The expected duration of the regime with stationary transfers is five years, so $p_{z}=.8$. This value corresponds to the amount of time before the CBO projects transfers will begin their sustained upward trajectory [Congressional Budget Office (2009)]. Again using CBO estimates, transfers grow at 1 percent per year once the switch from the stationary to non-stationary regime occurs, $\mu=1.01$.

After the switch to the regime with exponentially growing transfers, the same monetary and fiscal rules remain in place until the economy hits the fiscal limit. In the benchmark calibration, the probability of hitting the fiscal limit increases as debt and taxes rise, driven by the growth in transfers. The probability of hitting the fiscal limit is time varying and obeys the logistic function (32). $\eta_{0}$ and $\eta_{1}$ are set so that the initial probability of hitting the fiscal limit is 2 percent. The probability rises as debt and taxes increase and reaches about 20 percent by 2075. Figure 1 describes how the probability of hitting the fiscal limit rises with the tax rate.

At the fiscal limit, tax rates remain constant, since the assumption embedded in the model is that further distortionary tax financing beyond a given point is no longer available. The tax rate at the limit is $\tau^{\max }=.23$. In the regime with stationary transfers, this tax rate supports a steady state debt-output ratio of 1.46. However, since transfers are well above their value in the stationary regime when the economy hits the fiscal limit, the level at which debt stabilizes is below 146 percent of GDP.

When the economy hits the fiscal limit and tax policy become active with rates are fixed at $\tau^{\max }$, the economy temporarily enters a period of triply active policies: monetary policy continues to target inflation and promised transfers are fully delivered. Triply active policies persist with probability $p_{22}=.70$, implying an expected duration of $3-1 / 3$ years. With probability $p_{23}=.05$ monetary policy switches to passively pegging the nominal interest rate $(\alpha=0)$ and with probability $p_{24}=.25$ transfers policy becomes passive. Passive transfers means that delivered transfers, $\lambda_{t} z_{t}$, are less than promised. We assume the regime with passive transfers and active monetary policy is absorbing $\left(p_{44}=1\right)$ : in the long run the economy transitions to a state in which lump-sum transfers stabilize debt, distorting tax rates are constant, and monetary policy actively targets inflation.

\section{Simulated Equilibrium Time Paths}

It is useful, before launching into numerical results, to describe the long-run equilibrium of the model.

7.1 The Long-Run Equilibrium In the absorbing state - the policy mix to which the economy eventually converges - we obtain a Ricardian equilibrium. Call the date at which the economy reaches the absorbing state, $T^{A}$. Tax rates are fixed at their limit, $\tau^{\max }$, monetary policy is active, and transfers policy adjusts to maintain the value of government 
debt at the level it reached at the beginning of period $T^{A}, b\left(T^{A}\right)$. Because transfers are lump sum and can convert to becoming lump-sum taxes when $\lambda_{t}<0$, delivered transfers (or lump-sum taxes) can adjust as needed to stabilize debt at $b\left(T^{A}\right)$ without any changes in equilibrium allocations or prices. In fact, the absorbing state is a new steady state in which allocations are a function of $\tau^{\max }$, the real interest rate is constant, and inflation returns to its initial steady state value.

We can use the government's budget constraint to back out the level of promised transfers. In period $T^{A}$

$$
\lambda_{T^{A}}=\frac{1}{z_{T^{A}}}\left[b\left(T^{A}\right)\left(1-R_{T^{A}-1} / \pi^{*}\right)+\tau^{\max } Y\left(\tau^{\max }\right)+m\left(\tau^{\max }\right)-\left(1 / \pi^{*}\right) m_{T^{A}-1}\right]
$$

where $m_{T^{A}-1}$ and $R_{T^{A}-1}$ denote real money balances and the nominal interest rate in the period before the absorbing state, $\pi^{*}$ is the initial steady state inflation rate, and $m\left(\tau^{\max }\right)$ and $Y\left(\tau^{\max }\right)$ are new steady state values of real money balances and output at the fiscal limit tax rate. In all periods, $K>0$, beyond $T^{A}$

$$
\lambda_{T^{A}+K}=\frac{1}{\mu^{K} z_{T^{A}}}\left[\left(1-\beta^{-1}\right) b\left(T^{A}\right)+\left(1-1 / \pi^{*}\right) m\left(\tau^{\max }\right)+\tau^{\max } Y\left(\tau^{\max }\right)-G\right]
$$

As expression (36) makes clear, in the absorbing state transfers policy passively adjusts in order to stabilize debt at $b\left(T^{A}\right)$, given the limiting tax rate and the steady state inflation rate.

As we now see, despite the fact that the economy converges with probability one to a Ricardian equilibrium in which active monetary policy can perfectly target inflation, in the transition to this long-run equilibrium monetary policy will be unable to control inflation.

7.2 Triply Active Policies at the Fiscal Limit We begin with a contrast of the difference between how exogenous and endogenous probabilities of a fiscal limit discussed in section 4 affect outcomes in the pre-limit period. We present counterfactuals in which we impose that regime changes occur at particular dates. Agents in the model do not know those dates ex-ante, but they do observe the regime changes when they occur. Agents use the probability distributions described above to form expectations and, at the time of a regime change, those expectations may shift discretely. If regime change does not occur, agents also update their beliefs about future policies.

The two counterfactuals have the same underlying driving process: deterministic growth in transfers of 1 percent per year, as shown in the lower right panel of figures 3 and 4 . Both experiments begin with a stable transfers process that switches to the growing process in 2015, where it remains over the full period. Shaded regions in the figures depict the triply active episode which is triggered by hitting the fiscal limit in 2040. For 25 years in these counterfactuals, promised transfers, which are growing as a share of GDP, are fully honored and financed by new debt issuance that, via the tax rule, generates higher future labor income taxes. Monetary policy is actively targeting inflation by raising nominal interest rates more than one-for-one with inflation. This policy mix is consistent with the conventional regime in new Keynesian monetary analyses [for example, Galí (2008) and Woodford (2003)].

Figure 3 depicts equilibrium outcomes from this experiment when there is a fixed probability of hitting the limit each period $\left(p_{L}=.02\right)$. In the context of figure $1, \eta_{1}=0$ and the logistic function is flat at probability .02, independent of the prevailing tax rate. 
In the period leading up to the fiscal limit, years 2010-2039, government debt rises steadily as a share of the GDP, bringing with it higher tax rates that discourage work effort and reduce output. Inflation and, through the active monetary policy rule, nominal interest rates, rise only very modestly in the pre-limit period. Modest inflation effects are a direct outgrowth of the time-invariant probability of the limit, as we shall see.
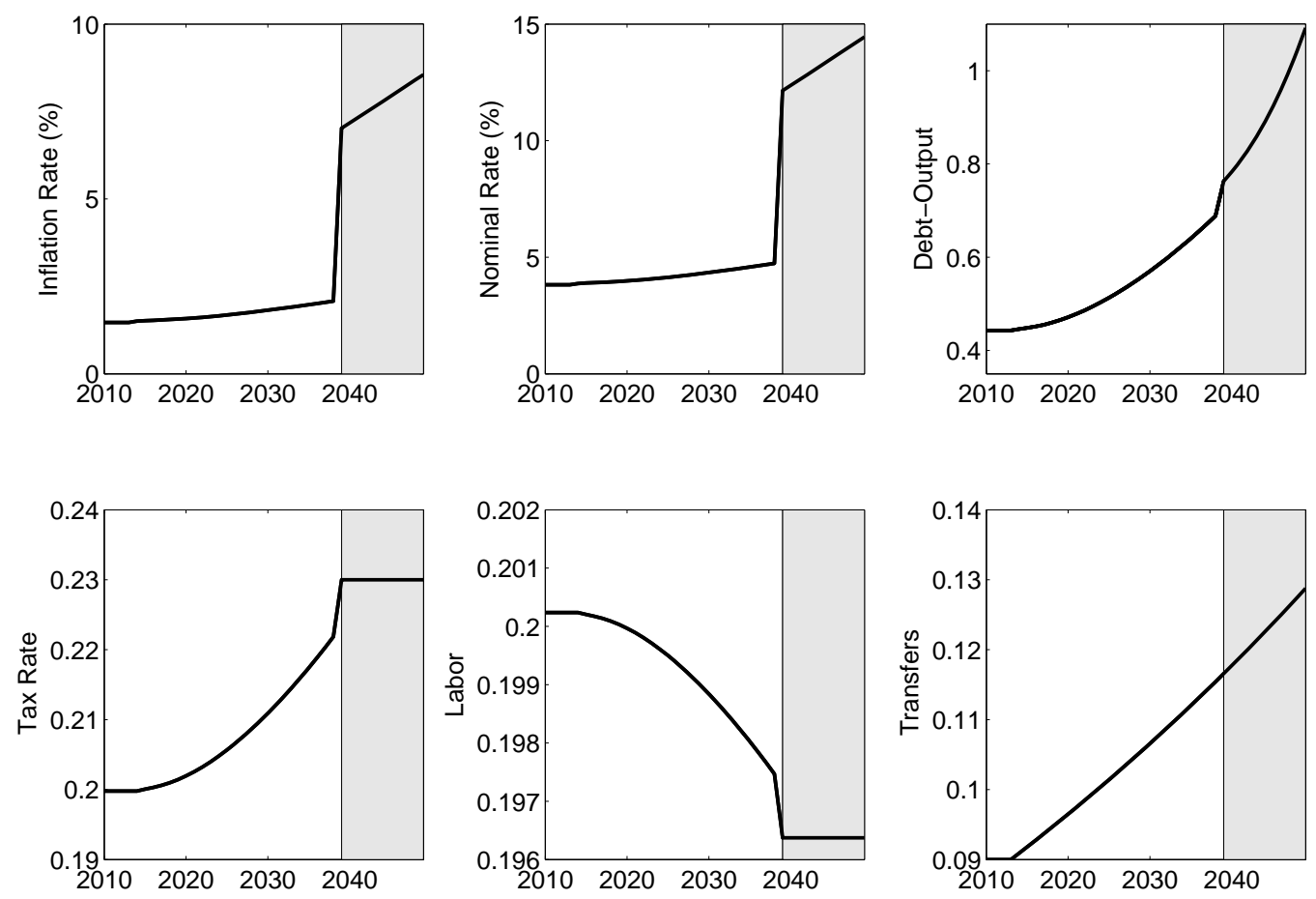

Figure 3: Simulated paths under a constant probability of hitting the fiscal limit. Shaded areas represent period of triply active policy.

When the limit is triggered in 2040 the tax rate jumps to the exogenously set $\tau^{\max }$ of .23 , generating corresponding drops in labor and output and increases in debt, inflation, and the nominal interest rate. At the limit-shaded regions in the figure - tax rates, labor, and output are constant. Inflation, however, begins to rise much more rapidly and debt begins to grow exponentially. ${ }^{12}$

Modeling the fiscal limit as state-dependent, as in the logistic function in figure 1, brings effects that occur in the triply active policy regime into the present, generating stronger impacts in the pre-limit period. Rising debt-financed transfers raise tax rates and, therefore, the probability of hitting the fiscal limit. A higher likelihood of moving to the triply active regime in which debt grows rapidly, raising inflation and the nominal interest rate, bringing

\footnotetext{
${ }^{12}$ Constancy of labor and output is due to flexible prices. Sticky price adjustment will imply that active monetary policy steadily raises real interest rates in an effort to combat inflation. Higher real rates will affect labor and consumption and it will also put debt growth on an even higher trajectory as real debt service increases.
} 
those effects into the pre-limit period.

Figure 4 superimposes the fixed-probability outcomes from figure 3 (solid lines) on those that emerge from a time-varying probability of the fiscal limit (dashed lines). At the fiscal limit, the two are identical. Leading up to the limit, however, a time-varying probability produces a jump in debt at the time that transfers begin to grow, which produces consistently higher debt and tax rate paths and lower labor path.
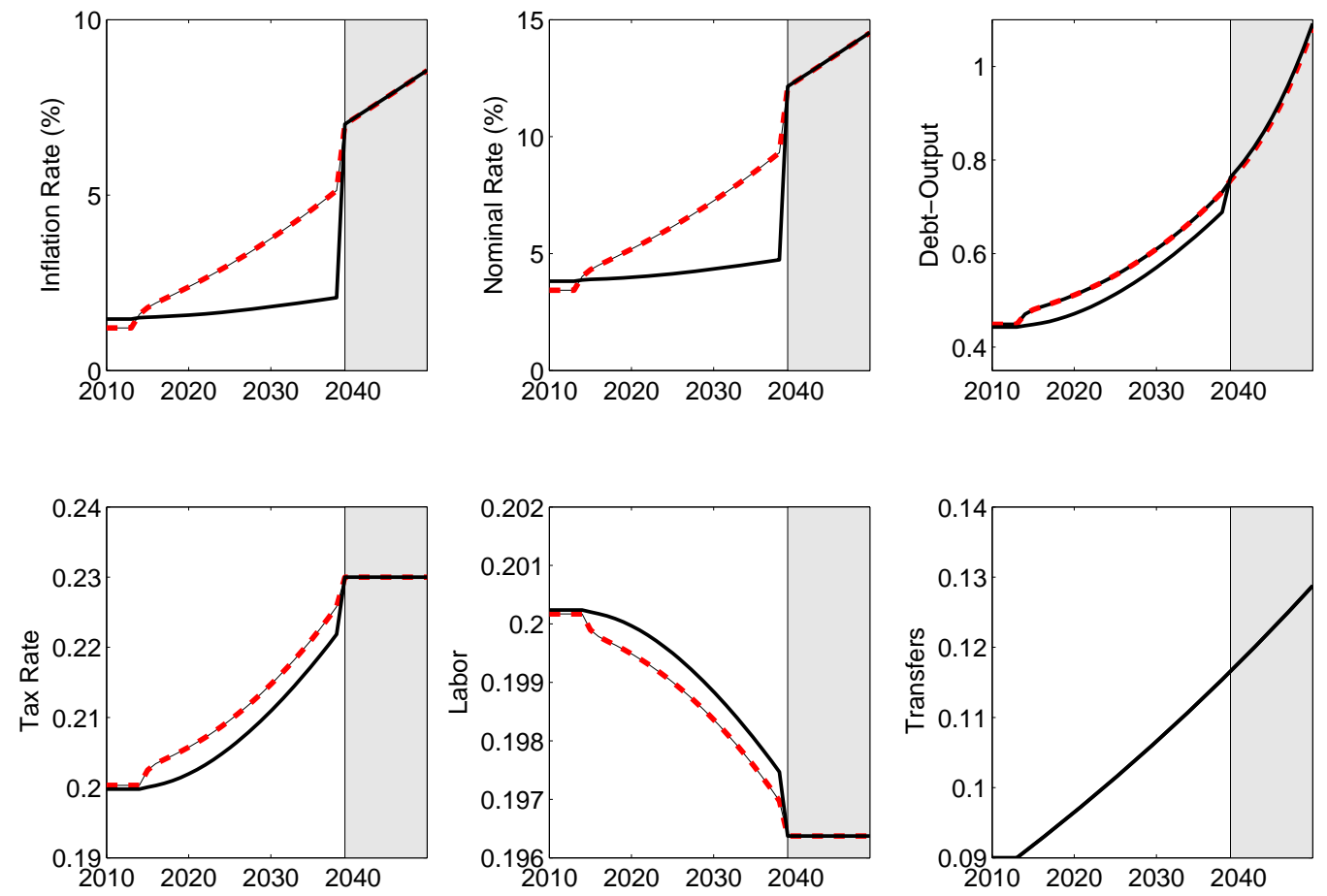

Figure 4: Simulated paths under a rising probability of hitting the fiscal limit (dashed lines) and a fixed probability of hitting the limit (solid lines). Shaded areas represent period of triply active policy.

It may be surprising that a rising probability of triply active policies or even the realization of such a regime produces rising inflation. After all, the dominant long-run (ergodic) regime is one in which delivered lump-sum transfers passively adjust to stabilize debt while monetary policy actively targets inflation. This is the canonical regime used to study inflation targeting [see, for example, Rudebusch and Svensson (1999) or any of the papers in Taylor (1999)]. How does the steady upward march of inflation from under 1.5 percent to 8.5 percent that appears in figure 4 arise?

Recall that in the triply active regime there is a small, .05, but positive probability of moving to a regime with passive monetary and active transfers policies. If the economy moves to that regime, it has an expected duration of 5 years before reaching the absorbing state of active monetary and passive transfers policies. A passive monetary/active transfers regime, if it were permanent, would produce a fiscal theory equilibrium in which debt is revalued 
through changes in the price level. In a fiscal theory equilibrium, inflation is determined by fiscal financing needs and not controlled by monetary policy. Hitting such a regime with one-period nominal debt produces a spike in the inflation rate, as Davig, Leeper, and Walker (2011) examine in detail.

In the counterfactuals we conduct, passive monetary policy is never realized, but it remains a possible policy outcome to which agents attach positive probability. Even a 5 percent chance of a fiscal theory outcome in the face of fiscal stress can drive the inflation rate up substantially, even if in the current regime monetary policy is aggressively targeting inflation.

One message that is robust to how the fiscal limit is modeled is that a monetary policy that satisfies the Taylor principle is unable to control inflation when the economy is staring at a fiscal limit where there is some chance that monetary policy will switch to being passive. State-dependence of the probability of the limit brings forward in time the effects of triply active policy behavior at the limit. Whether monetary policy loses control of inflation is not in question, but the modeling of the fiscal limit matters for how severely the loss of control manifests in higher inflation.

7.3 The Role of Monetary Policy It is remarkable that only a 5 percent chance of passive monetary policy can trigger a substantial run-up in inflation. Inflation rises monotonically with the likelihood of passive monetary policy. Figure 5 shows the cumulative rise in the price level if the economy remains in the active monetary/passive tax/active transfers regime for 35 years, as a function of the probability of passive monetary policy. Even quite modest probabilities that the central bank will shift from targeting inflation to stabilizing debt can produce substantially higher inflation rates.

How much inflation occurs depends, not only on the probability of passive monetary policy, as figure 5 shows, but also on how much debt has accumulated before the economy reaches its fiscal limit. Figure 6 reports the relationship between inflation and debt. Because promised - and, in the period before the fiscal limit, delivered - transfers are growing exponentially, government debt in the period also grows as a share of GDP. The longer it takes for the economy to hit the fiscal limit, the more debt builds up and the larger is the burst of inflation that occurs if monetary policy turns passive at the limit. This relationship stems from the logic of the fiscal theory. In the context of expression (13), at the fiscal limit the denominator is a fixed number, so the higher is the debt-output ratio, the higher will be inflation when monetary policy switching to being passive.

\section{Bad News About Future Surpluses}

Equilibrium paths in the previous section paint a picture of a fiscal limit that is well into the future and approaching only slowly. The dynamics arise from a low and slowly rising probability of hitting the fiscal limit. In practice, however, fiscal crises typically arise abruptly and then usually force sharp policy adjustments. In our framework, this suggests that the probability of hitting the fiscal limit remains low and stable until some news arrives that discretely shifts perceptions about future fiscal prospects. A sudden jump in fiscal pressures can arise from a number of factors: revelations that a country's accounting practices were less than fully transparent and masked its fiscal shortfalls (as in the case of Greece); election outcomes that induce fiscal consolidation sooner than expected (as is happening in the 


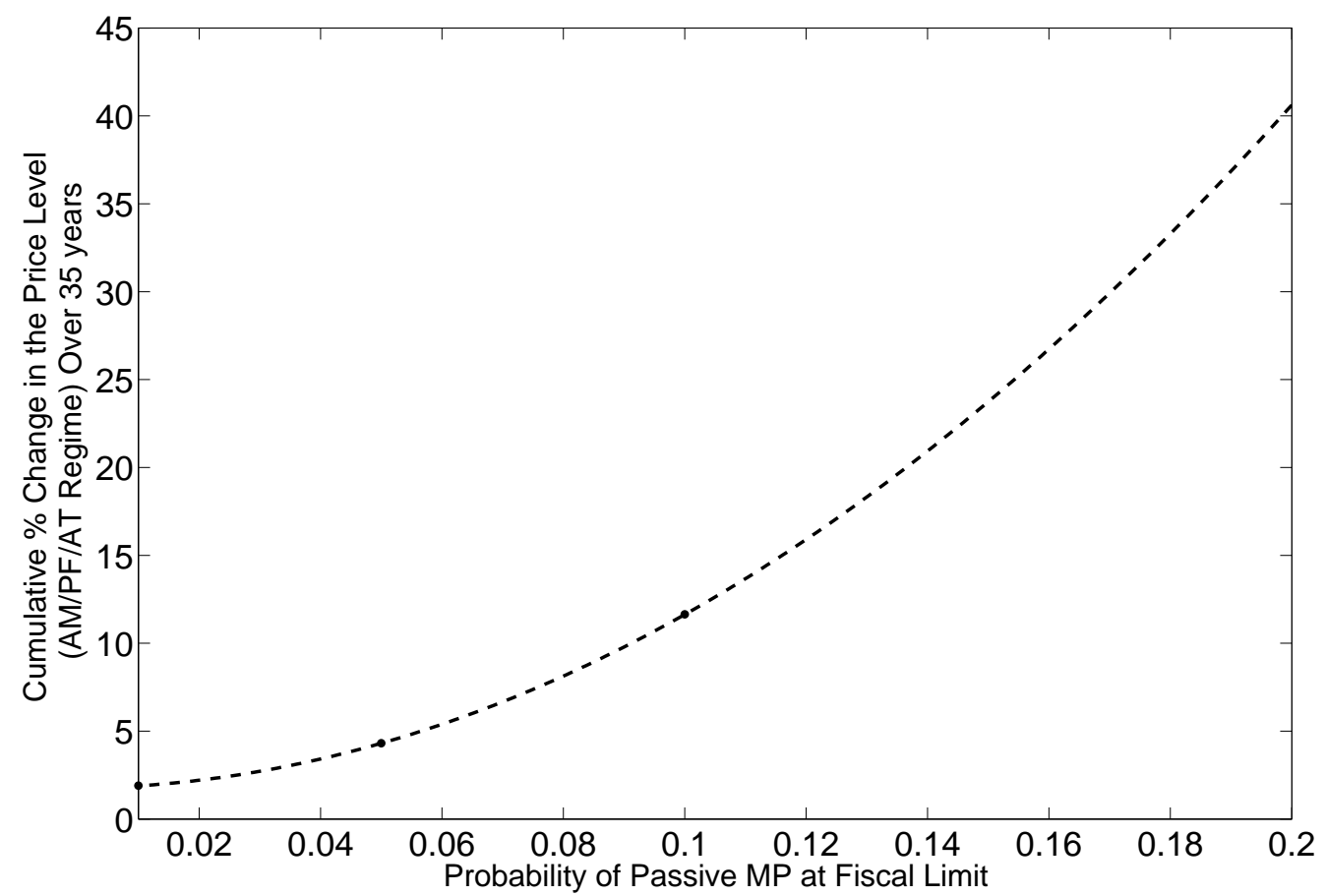

Figure 5: Cumulative price level increase, in percent, in the period before the fiscal limit, as a function of the probability of passive monetary policy at the fiscal limit. Period of active monetary, passive tax, and active transfers policies lasts 35 years in each case.

United Kingdom); surprising growth in the political clout of anti-tax constituencies (the tea party movement in the United States). Although each of these can have important economic consequences, they are not, in the first instance, entirely reactions to the state of the economy. Each contains an important exogenous component.

Figure 7 illustrates the evolution of future fiscal regimes and the corresponding probabilities of transiting from one regime to another. The top portion of the diagram is the same as in the previous section, except the framework is modified to now allow a change in the expected future tax rate at the fiscal limit. In the regime where transfers are steadily growing, households now have a distribution over future tax rates at the fiscal limit. Previously, all probability mass was attached to a single limiting tax rate, whereas now households believe there are two possible limiting tax rates. We endow households with an expectation that with probability $p_{N}$, the tax rate at the fiscal limit will be $\tau_{\text {low }}^{\max }=.22$, rather than $\tau^{\max }=.23$. This apparently minor adjustment substantially affects of the amount of debt that can be supported when the economy returns to its steady state. At the initial level of steady state transfers, the .23 tax rate supports a debt-output ratio of 146 percent; a .22 tax rate reduces the ratio to 112 percent. $p_{N}$ is set to a low value, .05, so that ex ante the lower limiting tax rate is unlikely to be realized. However, if events materialize that reveal a country has less capacity to tax than previously believed, or voters revolt and demand lower future taxes, then expectations move to the lower branch of the diagram in figure 7 . The news shock is realized. Policy regimes do not change: monetary policy remains active, tax policy remains 


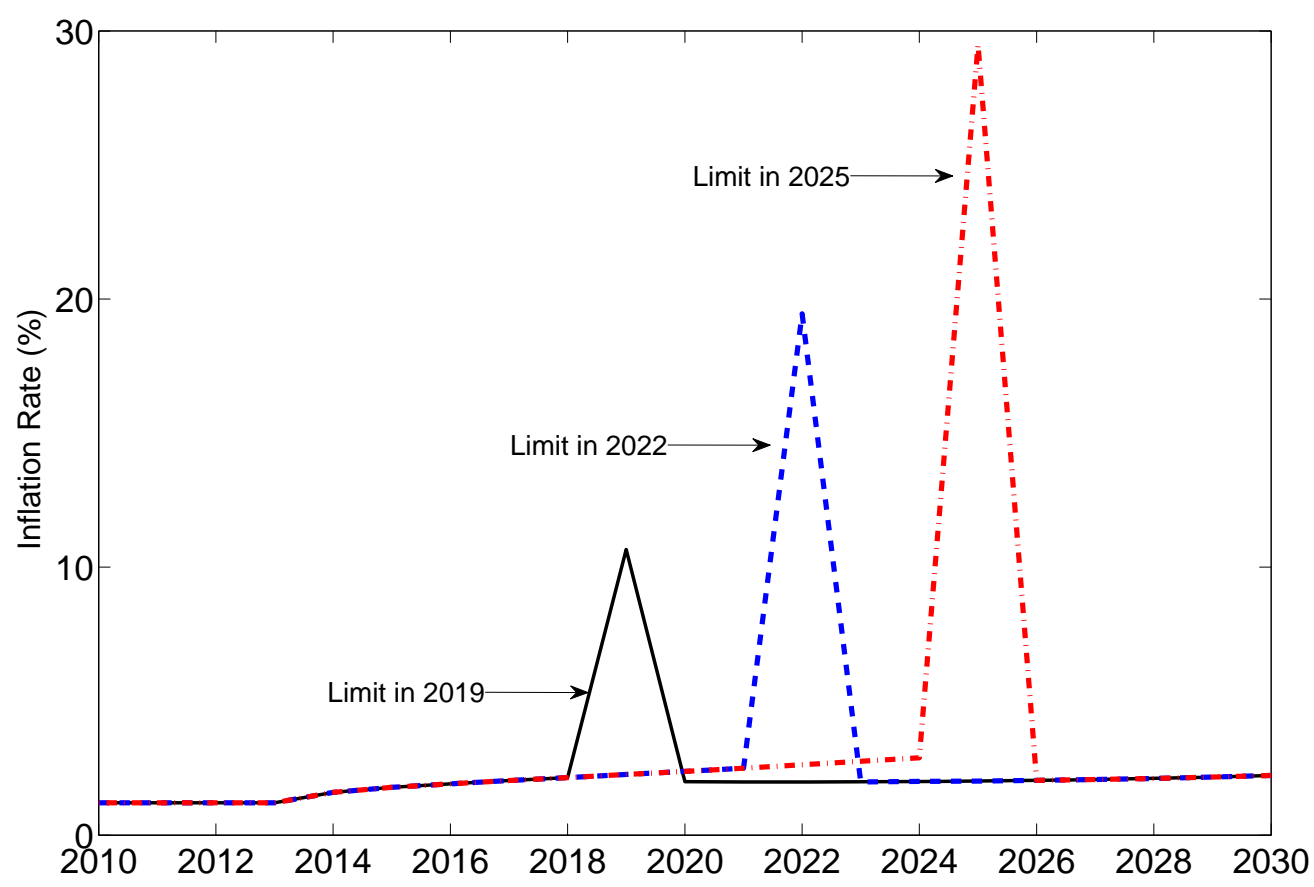

Figure 6: Relationship between inflation and debt when fiscal limit is realized at different dates and passive monetary policy occurs.

passive, and the promised transfers continue to be fully delivered.

To model a sudden rise in the probability of hitting the fiscal limit, we allow a jump in the probability by allowing a shock to expected future tax rates. Modify the logistic function used to determine the probability of the fiscal limit as

$$
p_{L, t}=1-\frac{\exp \left(\eta_{0}-\eta_{1}\left(\tilde{\tau}_{t-1}-\tau^{*}\right)\right)}{1+\exp \left(\eta_{0}-\eta_{1}\left(\tilde{\tau}_{t-1}-\tau^{*}\right)\right)},
$$

with $\tilde{\tau}_{t-1}=\tau_{t-1}-\xi_{t-1}$ and $\xi_{t}=\xi_{t-1}+\zeta_{t}$, where

$$
\zeta_{t}= \begin{cases}\bar{\zeta}>0 & \text { with probability } p_{N} \\ 0 & \text { with probability } 1-p_{N}\end{cases}
$$

This specification has the effect of permanently changing the limiting tax rate from $\tau^{\max }$ to $\tau_{\text {low }}^{\max }=\tau^{\max }-\bar{\zeta}$. Suppose that no news arrives until period $t-1$, so $\xi_{t-2}=0$, but at $t-1$ people learn that the limiting tax rate will be lower than previously believed. A lower expected present value of tax revenues reduces the level of government debt that the economy can support. Figure 8 depicts how the economy's logistic function discretely shifts up the probability of hitting the fiscal limit.

Shifts in expectations from news shocks can have a substantial impact. Figure 9 compares the equilibrium path from the last section (solid lines), to the path when a news shock is realized (dashed lines). In the period of the shock, households come to expect a lower tax rate 


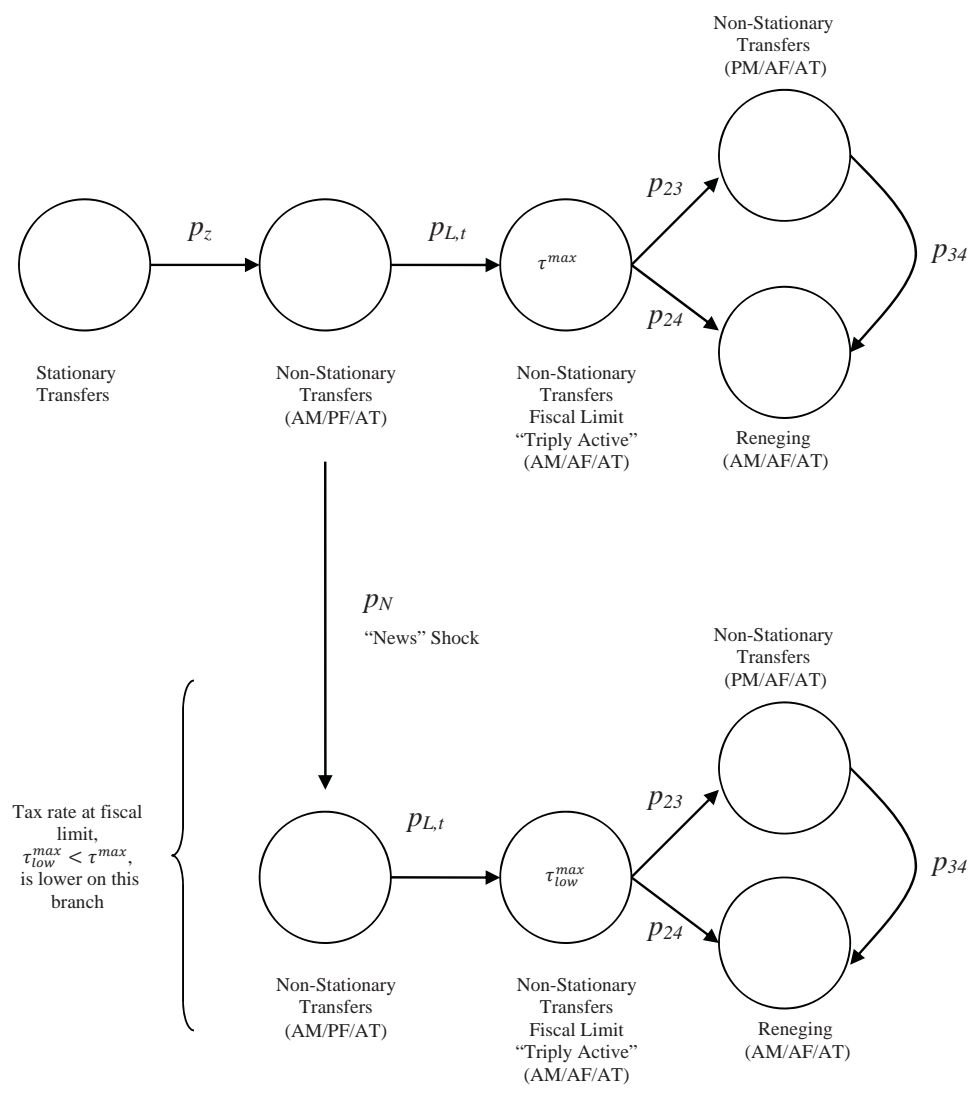

Figure 7: Evolution of policy regimes. Upper branch identical to figure 2: $p_{Z}$ : probability of non-stationary transfers process; $p_{L, t}$ : probability of fiscal limit; AM: active monetary policy; PF: passive fiscal policy; AT: active transfers policy; PM: passive monetary policy; AF: active fiscal policy; PT: passive transfers policy. Lower branch: with probability $p_{N}$ news arrives that reduces the expected present value of tax revenues because the limiting tax rate becomes $\tau_{\text {low }}^{\max }<\tau^{\max }$.

at the fiscal limit than they had previously. News also causes an immediate upward shift in the probability attached to hitting the limit. Paths of endogenous variables shift in response to the news. Essentially, the news pulls forward many of the effects from the previous section. A higher probability of hitting the fiscal limit raises inflation, inflation expectations, and the nominal interest rate. Inflation rises because the economy is now closer to its fiscal limit and the possibility that monetary policy will turn passive, an outcome that brings with it a burst of inflation. Higher debt in the period of the shock stems from households rebalancing their portfolios: a higher nominal rate induces households to substitute out of holding real money balances and into debt. But lower real balances also reduce seigniorage revenues, requiring still further sales of new debt to cover the shortfall. Because tax policy remains passive, tax rates rise along with debt.

An interesting feature of the news shock is that it reduces agents' beliefs about taxes in the long run. In figure 9, the lower limiting tax rate is not realized, so there is no data that would indicate why agents adjusted their behavior in response to the tax news. And because 


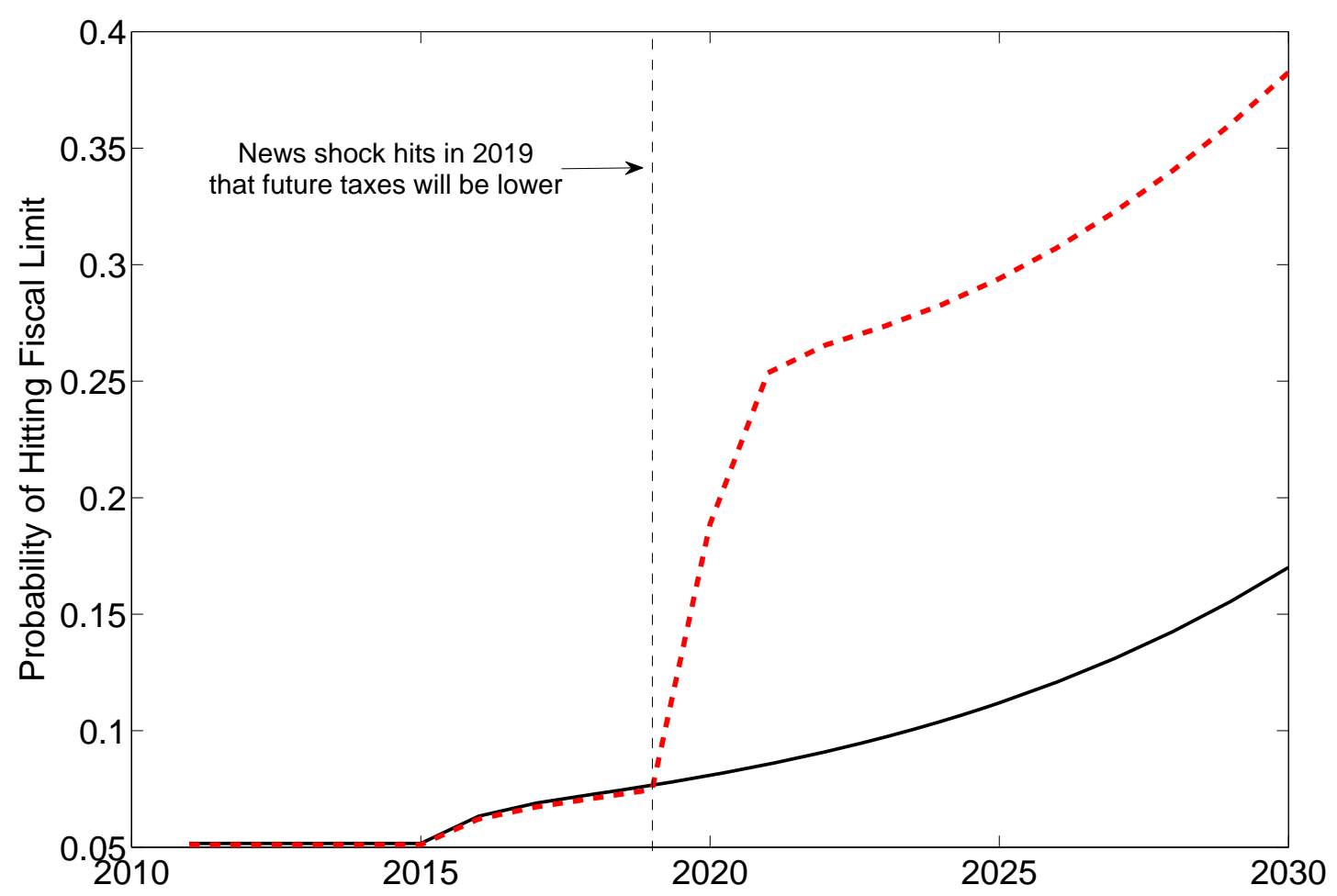

Figure 8: News about lower expected present value of tax revenues discretely shifts up the probability of hitting the fiscal limit in year 2019.

the news pertains to long-run fiscal decisions, it will be difficult to detect the source of the fiscal crisis using conventional macroeconomic time series.

\section{Concluding Remarks}

As countries enter an era of fiscal stress, policymakers will confront the implications of that stress, and its associated uncertainty, for inflation and the ability of monetary policy to control inflation and affect the economy in the usual ways. Debt can assume an explosive trajectory in periods when taxes are unable to move higher for political reasons and central banks continue to fight inflation aggressively. Explosive debt dynamics push countries toward their fiscal limits and can have powerful effects on inflation that depend on expectations of future monetary and fiscal policies. In most countries, political institutions do not anchor fiscal expectations on policies that would prevent inflation.

Sargent and Wallace (1981) taught us that if fiscal policy persists in running exogenous primary surpluses, then eventually monetary policy must submit and stabilize debt, with the inevitable result of high inflation. This paper makes the remarkable point that even if long-run policies give monetary policy perfect control over inflation, in the transition to that long run, monetary policy can spectacularly lose control. Monetary policy's control of inflation may be even more fragile that Sargent and Wallace depict. 

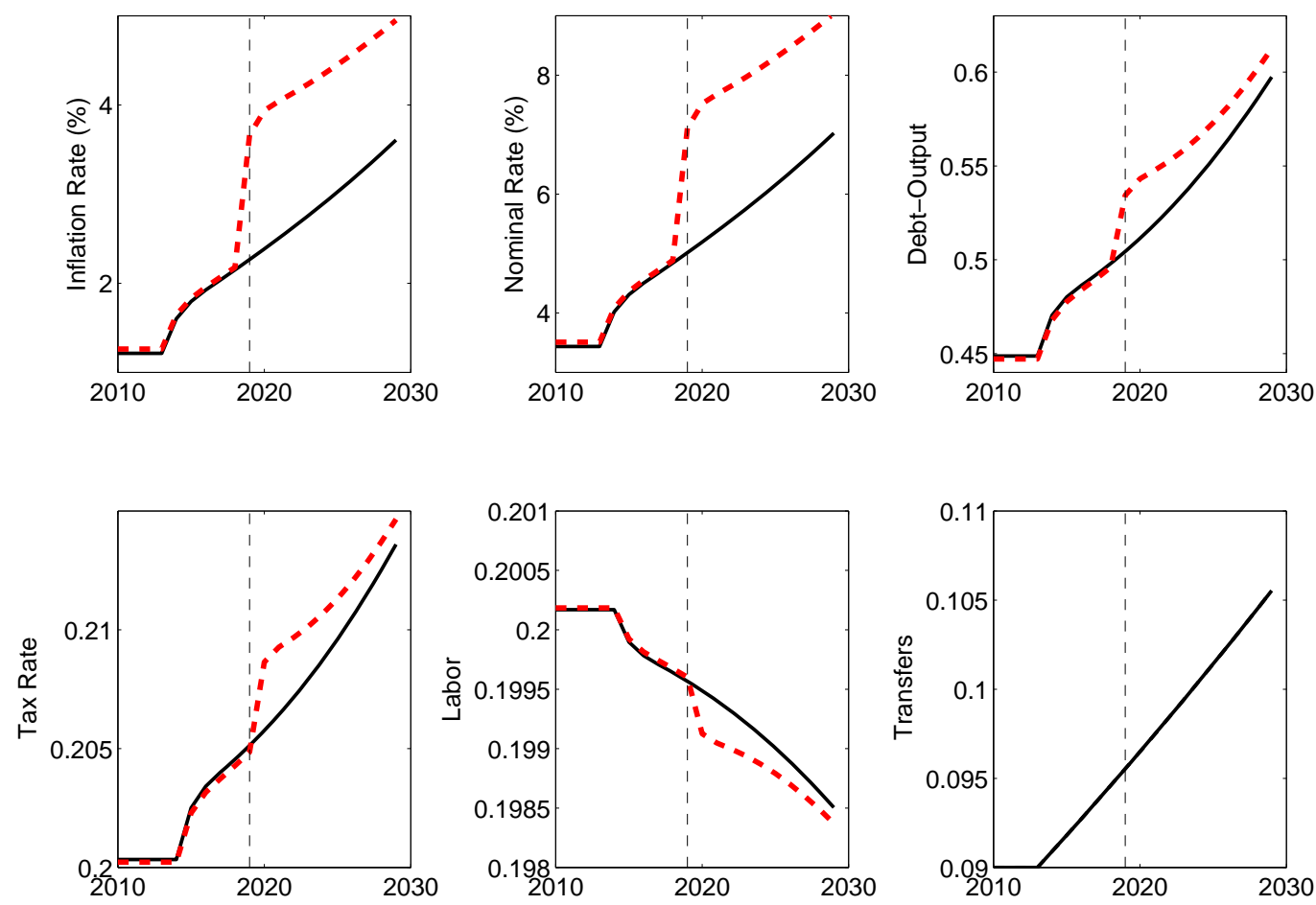

Figure 9: Simulated time paths in the period before the fiscal limit without - solid lines - and with - dashed lines - news about lower expected present value of tax revenues. News arrives in 2019. Policy before the fiscal limit is active monetary, passive tax, and active transfers policies.

In 2010, despite the long-term fiscal shortfalls that advanced economies face, expectations of future inflation are stable and low. Some observers have inferred from this that fiscal imbalances are not a concern for monetary policy. There is little doubt, however, that in the absence of long-term fiscal reforms, many countries will hit their fiscal limits, so why are we not seeing evidence that inflation is on the rise?

Several possibilities suggest themselves. First, as Davig, Leeper, and Walker (2011) show, stable inflation expectations are not necessarily anomalous. They can arise if expectations center on substantial entitlements reforms in the future, with little probability that monetary policy will move away from targeting inflation aggressively. Second, with only a few exceptions, major economies continue to operate well below their fiscal limits, despite the rapid increase in debt stemming from the recession and financial crisis. A country that is far from its fiscal limit would have no reason to expect creeping inflation due to fiscal shortfalls. Third, the simulations in Davig, Leeper, and Walker (2011) also show that even if the mean of expected inflation is benign, there may be tail events in which inflation is quite high. A small probability of very high inflation plays a critical role in the existence of the rational expectations equilibrium.

Finally, results in previous papers that show how benign inflation can be consistent with 
an era of fiscal stress rely heavily on economic agents having clear understandings of the possible policy adjustments and their probabilities. They also rely on shifting to policy regimes that always stabilize government debt. This paper has explored two ways in which such an innocuous outcome may not occur: policy authorities may not coordinate to ensure that some stabilizing policy is always in place and news that discretely shifts agents' views about long-run fiscal prospects can trigger sudden increases in inflation.

The policy scenarios we have considered, in which fiscal stress feeds into inflation, are not merely possible: they are plausible in countries in which policy institutions do not adequately anchor expectations of fiscal policy. 


\section{REFERENCES}

BI, H. (2009): "Sovereign Risk Premia, Fiscal Limits and Fiscal Policy," Manuscript, Indiana University.

Black, F. (1972): "Active and Passive Monetary Policy in a Neoclassical Model," Journal of Finance, 27(4), 801-814.

Buiter, W. H. (2002): "The Fiscal Theory of the Price Level: A Critique," Economic Journal, 112(481), 459-480.

Cagan, P. (1956): "The Monetary Dynamics of Hyperinflation," in Studies in the Quantity Theory of Money, ed. by M. Friedman, pp. 25-117. University of Chicago Press, Chicago.

Chari, V. V., P. J. Kehoe, and E. R. McGrattan (2000): "Sticky Price Models of the Business Cycle: Can the Contract Multiplier Solve the Persistence Problem?," Econometrica, 68(5), 1151-1179.

Cochrane, J. H. (1999): "A Frictionless View of U.S. Inflation," in NBER Macroeconomics Annual 1998, ed. by B. S. Bernanke, and J. J. Rotemberg, vol. 14, pp. 323-384. MIT Press, Cambridge, MA.

- (2007): "Inflation Determination with Taylor Rules: A Critical Review," Manuscript, University of Chicago.

Congressional Budget Office (2009): An Analysis of the President's Budgetary Proposals for Fiscal Year 2010. CBO, Washington, D.C., June.

(2010): The Long-Term Budget Outlook. CBO, Washington, D.C., June.

DAvig, T. (2005): "Periodically Expanding Discounted Debt: A Threat to Fiscal Policy Sustainability?," Journal of Applied Econometrics, 20(7), 829-840.

Davig, T., And E. M. Leeper (2006): "Fluctuating Macro Policies and the Fiscal Theory," in NBER Macroeconomics Annual 2006, ed. by D. Acemoglu, K. Rogoff, and M. Woodford, vol. 21, pp. 247-298. MIT Press, Cambridge.

(2011): "Monetary-Fiscal Policy Interactions and Fiscal Stimulus," European Economic Review, 55(2), 211-227.

Davig, T., E. M. Leeper, and T. B. Walker (2010): “'Unfunded Liabilities' and Uncertain Fiscal Financing," Journal of Monetary Economics, 57(5), 600-619.

(2011): "Inflation and the Fiscal Limit," European Economic Review, 55(1), 31-47.

Eaton, J., and M. Gersovitz (1981): "Debt with Potential Repudiation: Theoretical and Empirical Analysis," Review of Economic Studies, 48(2), 289-309.

Eusepi, S., And B. Preston (2010): "Debt, Policy Uncertainty and Expectations Stabilization," Forthcoming in Journal of the European Economic Association. 
Friedman, M. (1948): "A Monetary and Fiscal Framework for Economic Stability," American Economic Review, 38(2), 245-264.

(1960): A Program for Monetary Stability. Fordham University Press, New York.

Galí, J. (2008): Monetary Policy, Inflation, and the Business Cycle. Princeton University Press, Princeton.

Gokhale, J., and K. Smetters (2007): "Do the Markets Care About the $\$ 2.4$ Trillion U.S. Deficit?," Financial Analysts Journal, 63(2), 37-47.

Hamilton, J. D., And M. A. Flavin (1986): "On the Limitations of Government Borrowing: A Framework for Empirical Testing," American Economic Review, 76(4), 808-819.

International Monetary Fund (2009): "Fiscal Implications of the Global Economic and Financial Crisis," IMF Staff Position Note SPN/09/13.

Leeper, E. M. (1991): “Equilibria Under 'Active' and 'Passive' Monetary and Fiscal Policies," Journal of Monetary Economics, 27(1), 129-147.

(2010a): "Anchors Away: How Fiscal Policy Can Undermine "Good" Monetary Policy," in Monetary Policy Under Financial Turbulence, 13th Annual Conference of the Central Bank of Chile. Banco Central de Chile, Santiago.

_ (2010b): "Monetary Science, Fiscal Alchemy," forthcoming in Federal Reserve Bank of Kansas City's Jackson Hole Symposium, Macroeconomic Challenges: The Decade Ahead.

McCallum, B. T. (2001): "Indeterminacy, Bubbles, and the Fiscal Theory of Price Level Determination," Journal of Monetary Economics, 47(1), 19-30.

Obstfeld, M., and K. Rogoff (1983): "Speculative Hyperinflations in Maximizing Models: Can We Rule Them Out?," Journal of Political Economy, 91(4), 675-687.

Olivera, J. H. (1970): "On Passive Money," Journal of Political Economy, 78, Part II(July/August), 805-814.

Rotemberg, J. J., And M. Woodford (1997): "An Optimization-Based Econometric Framework for the Evaluation of Monetary Policy," in NBER Macroeconomics Annual 1997, ed. by B. S. Bernanke, and J. J. Rotemberg, vol. 12, pp. 297-346. MIT Press, Cambridge, MA.

Rudebusch, G., and L. E. O. Svensson (1999): "Policy Rules for Inflation Targeting," in Monetary Policy Rules, ed. by J. B. Taylor, pp. 203-246. University of Chicago Press, Chicago.

Samuelson, P. A. (1967): "Stabilization Policies in the Contemporary U.S. Economy," in Monetary Process and Policy: A Symposium, ed. by G. Horwich, pp. 3-11. Richard D. Irwin, Homewood, IL. 
Sargent, T. J. (1986): "Reaganomics and Credibility," in Rational Expectations and Inflation, chap. 2. Harper \& Row, New York.

Sargent, T. J., And N. Wallace (1981): "Some Unpleasant Monetarist Arithmetic," Federal Reserve Bank of Minneapolis Quarterly Review, 5(Fall), 1-17.

Simons, H. C. (1936): "Rules versus Authorities in Monetary Policy," Journal of Political Economy, 44(1), 1-30.

Sims, C. A. (1994): "A Simple Model for Study of the Determination of the Price Level and the Interaction of Monetary and Fiscal Policy," Economic Theory, 4(3), 381-399.

\section{0's," European Economic Review, 55(1), 48-56.}

Taylor, J. B. (ed.) (1999): Monetary Policy Rules. University of Chicago Press, Chicago.

Trabandt, M., and H. Uhlig (2009): "How Far Are We From the Slippery Slope? The Laffer Curve Revisited," NBER Working Paper No. 15343.

Woodford, M. (1995): "Price-Level Determinacy Without Control of a Monetary Aggregate," Carneige-Rochester Conference Series on Public Policy, 43, 1-46.

- (1998): "Control of the Public Debt: A Requirement for Price Stability?," in The Debt Burden and Its Consequences for Monetary Policy, ed. by G. Calvo, and M. King, pp. 117-154. St. Martin's Press, New York.

- (2001): "Fiscal Requirements for Price Stability," Journal of Money, Credit, and Banking, 33(3), 669-728.

(2003): Interest and Prices: Foundations of a Theory of Monetary Policy. Princeton University Press, Princeton, N.J. 